\title{
X-Ray Structural Investigations of Gold Compounds
}

\section{A COMPILATION OF REFERENCE DATA. PART I}

\author{
Peter G. Jones
}

Inorganic Chemiṣtry Institute, University of Göttingen, Federal Republic of Germany

Our knowledge of the structural chemistry of gold has been advanced in recent years by the use of X-ray techniques to the point where achievements in this field can be constructively discussed. In this article - Part II of which will appear in the next issue of Gold Bulletin - the literature on the subject (intermetallic compounds of gold excepted) up to early 1980 is reviewed comprehensively and some selected, more recent examples are discussed.

The use of X-ray crystallographic methods, both as an analytical tool and as a means of obtaining detailed structural information at the atomic level, is nowadays extremely widespread. This may be attributed to the development of fast, accurate and elegant diffractometers, computers and software at prices accessible to most large research establishments. The consequent volume of available $\mathrm{X}$-ray structural data has rendered review articles of considerable usefulness. This review examines the structural chemistry of gold as revealed by X-ray studies.

The problem of performing an exhaustive literature search is no small one. The author has made frequent use of the stored data and search programs of the Cambridge Crystallographic Data Centre, and would like to express gratitude to Dr. O. Kennard and coworkers for their assistance. The BIDICS series of publications (Dr. I. D. Brown and co-workers, McMaster University, Canada) has also been an essential source. It is hoped that the review is comprehensive up to Spring 1980, or, at least, that accidental omissions have been kept to a minimum. Where appropriate, some recently published results have also been included. Unpublished results have kindly been made available to me by the following colleagues: Prof. H. Schmidbaur, Prof. J. Strähle and Dr. P. R. Raithby.

For reasons of space it is not possible to give here a description of crystallographic methods. Suffice it to say that the results of a structure determination consist quantitatively of lists of atomic coordinates and derived parameters such as bond lengths and angles, and qualitatively of a picture of the molecule. (The principle that one picture is worth a thousand words is nowhere more applicable than in structural chemistry, and for this reason a representative sample of diagrams is given here.) The more interesting of these results form the bulk of this review; for further details of individual structures the reader must have recourse to the original articles. The practice of publishing crystal structures without lists of coordinates is strongly to be deprecated, although becoming less common with the introduction of deposition schemes for crystallographic data. References in which no coordinates are quoted are labelled 'nc'.

The (somewhat arbitrary) sections into which this article is divided are as follows:

I. Simple Binary and Ternary Compounds

II. Cluster Compounds

III. Compounds with Gold-Transition Metal Bonds

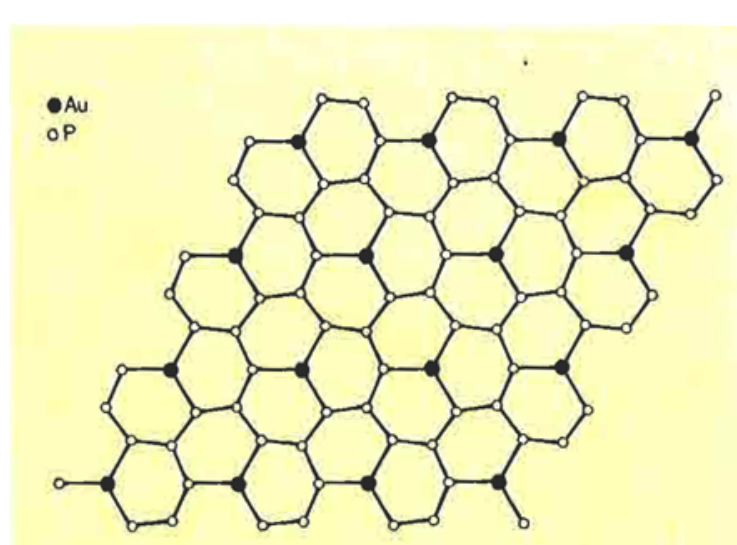

Fig. 1 Part of the gold-phosphorus net in $\mathrm{Au}_{7} \mathrm{P}_{10} \mathrm{I}$ projected down the $z$ axis. After (1) 


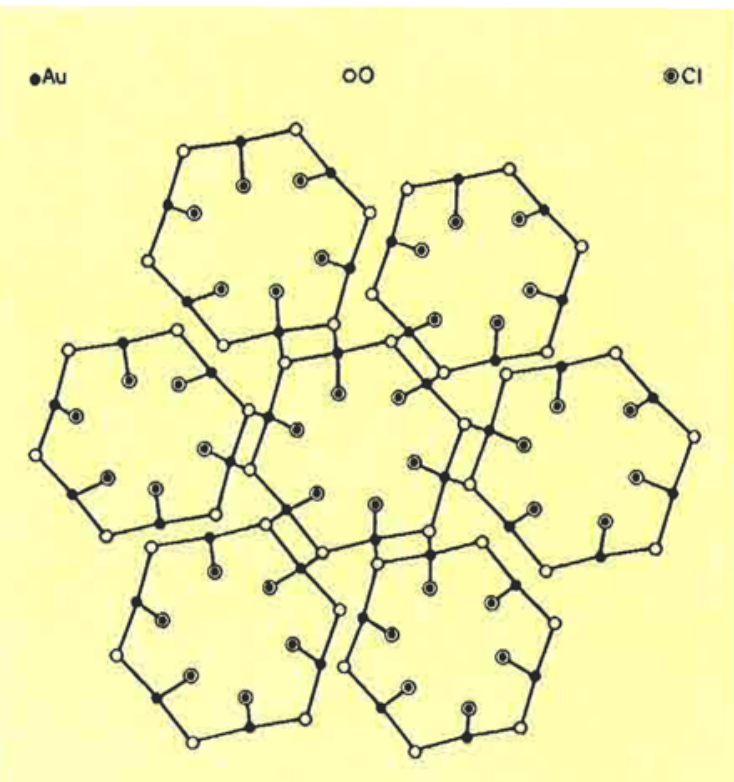

Fig. 2 The structure of AuOCl seen in perspective down the hexagonal $z$ axis. After (3)

IV. Gold(I) Complexes with Short Au...Au Contacts

V. Other Linear Gold(I) Complexes

VI. Gold(I) Complexes with Higher Coordination number

VII. Square Planar Gold(III) Complexes

VIII. Gold(III) Complexes with Higher Coordination number

IX. Mixed Au(I)-Au(III) Species

X. Unusual Oxidation States: Au(II) and Au(V)

It is well-known (and implied in the section headings) that the archetypal coordination geometries for $A u(I)$ and $A u(I I I)$ are linear and square planar respectively. This will be assumed without further comment.

\section{Simple Binary and Ternary Compounds}

\section{Group Vb Derivatives}

No simple gold phosphides are known. $\mathrm{Au}_{2} \mathrm{P}_{3}(1)$ consists of $\mathrm{P}_{6}^{4-}$ rings linked both directly and through $A u^{1}$ atoms (P-Au-P 180 and $171^{\circ}$ ). The related $A u_{7} P_{10} I(1)$, formally $A u_{7}^{1}\left(P_{10}\right)^{6} I$; possesses infinite sheets of $P_{12}$ rings containing three-coordinate $A u^{\mathrm{I}}$ atoms (Figure 1). These sheets are joined by linear P-Au-P and (weaker) Au-I-Au bridges.

$\mathrm{Na}_{2} \mathrm{AuX}$ (X = As or $\mathrm{Sb}$ ) (la) contains infinite zigzag chains of empirical formula $A \mathrm{AX}^{2-}$, resembling the isoelectronic gold(I) halides (see below). Au-X distances are 250.1 and $264.9 \mathrm{pm}$ for $\mathrm{X}=\mathrm{As}$ and $\mathrm{Sb}$, respectively. The angles at $\mathrm{X}$ are suprisingly acute (70.3 and $66.9^{\circ}$, respectively).

\section{Group VIb Derivatives}

Gold(III) oxide $\left(\mathrm{Au}_{2} \mathrm{O}_{3}\right)$ (2) shows an interesting variation in $\mathrm{Au}-\mathrm{O}$ bond lengths. One oxygen atom is coordinated to two $\mathrm{Au}$ atoms, and has the shortest Au-O bond (193 pm), the other to three Au atoms with appreciably longer bonds (201, 204 and 207 $\mathrm{pm}$ ), the longest being trans to the $193 \mathrm{pm}$ bond. The extended structure is polymeric and best seen as a stereoview (2).

Gold(III) oxychloride (AuOCl) (3) is a polymer consisting of linked hexameric rings (Figure 2). A trans influence - the lengthening of a metal-ligand bond by the ligand trans to it - is again observed, the Au-O bond trans to $\mathrm{Cl}$ being appreciably longer than the other two (207 against 199 and $201 \mathrm{pm}$ ).

AuSe (4) crystallizes in two forms, both containing linear and square coordinated $\mathrm{Au}$ atoms; the formulation $\mathrm{Au}^{\mathrm{I}} \mathrm{Au}^{\mathrm{III}} \mathrm{Se}_{2}$ is thus appropriate (see section IX). Average $\mathrm{Au}^{\mathrm{I}}-\mathrm{Se}$ and $\mathrm{Au}^{\mathrm{II}}$-Se bond lengths are 243 and $248 \mathrm{pm}$ in $\alpha$-AuSe, and 243 and $250 \mathrm{pm}$ in $\beta$-AuSe. In both cases the crystal quality was poor, but adequate for structure determination.

Gold(III) selenide bromide (AuSeBr) (5) displays a ribbon structure (Figure 3). There are two independent gold sites, one coordinated by two Se and two $\mathrm{Br}$, the other by four $\mathrm{Se}$. $\mathrm{The} \mathrm{Br}$ atoms are terminal. There are considerable deviations from ideal square planar coordination at $\mathrm{Au}$.

The compounds $\mathrm{AuTe}_{2} \mathrm{X}$ (X = C1 or I) (6) may be considered as $\left[\mathrm{Au}^{\mathrm{III}}\left(\mathrm{Te}_{2}\right)_{4 / 4}\right]^{+} \mathrm{X}^{-}$. (The 4/4 notation means that each gold atom is bonded to four $\mathrm{Te}_{2}$ units and each $\mathrm{Te}_{2}$ unit to four Au atoms.) Both structures contain corrugated two-dimensional nets of $\mathrm{Au}$ and Te atoms (Figure 4). $\mathrm{Te}_{2}$ units bridge neighbouring $\mathrm{Au}^{\mathrm{III}}$ centres, and the Au-Te distances are 267.4 and $268.8 \mathrm{pm}$ for $\mathrm{X}=\mathrm{Cl}$ and I respectively. Again, some deviation from ideal geometry at Au is observed. The

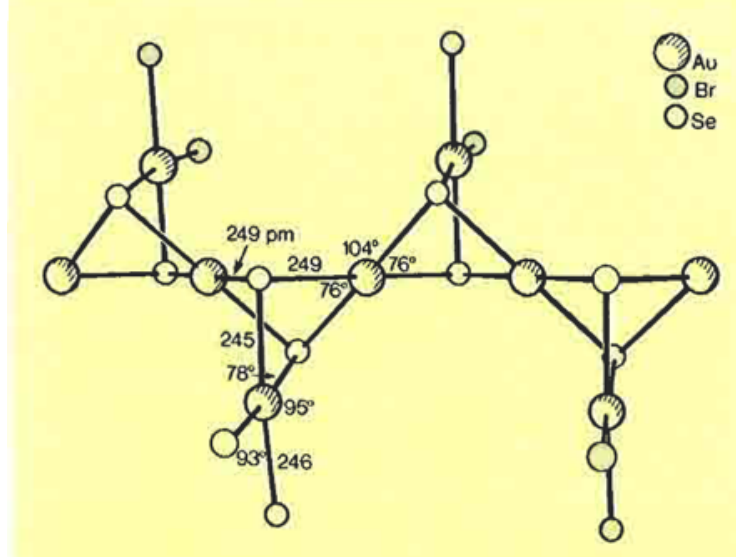

Fig. 3 Part of the ribbon structure of the compound AuSeBr. After (5) 


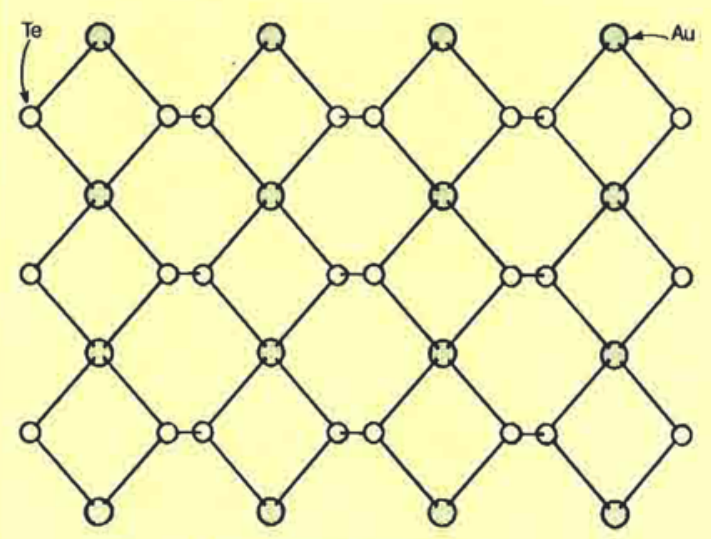

Fig. 4 Part of the gold-tellurium sheet in $\mathrm{AuTe}_{2} \mathrm{Cl}$ projected down the $y$ axis. After (6)

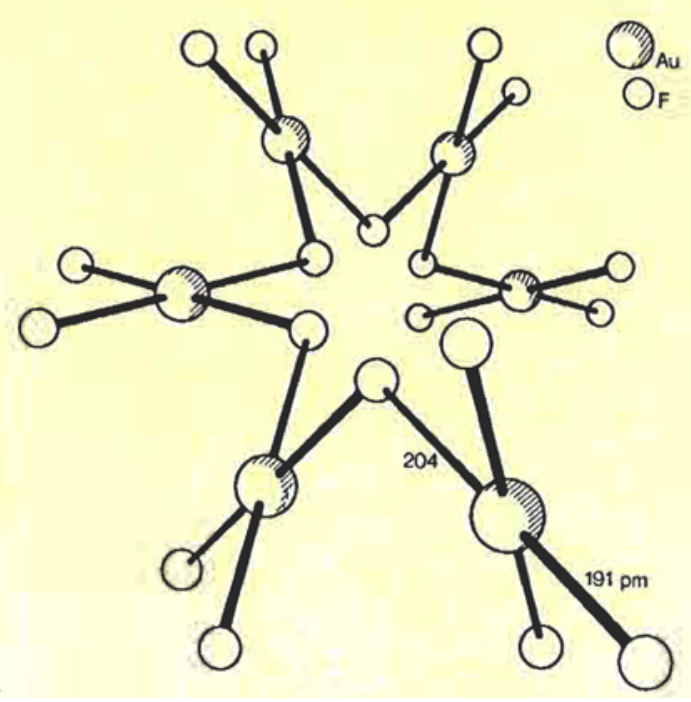

Fig. 5 The helical structure of $A u F_{3}$ seen in exag. gerated perspective down the $z$ axis. After (9)

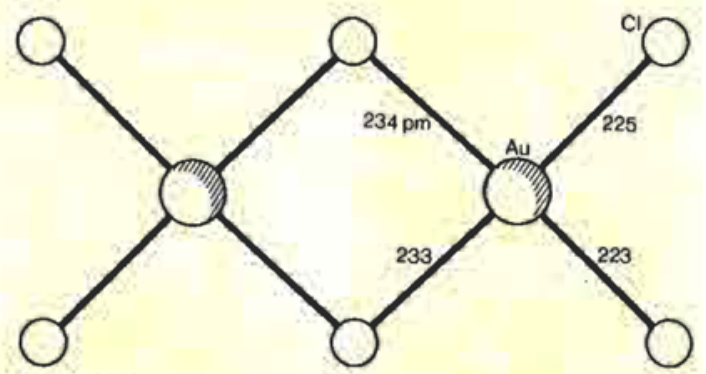

Fig, 6 The dimeric structure of gold(1II) chloride. The structure of gold(III) bromide is analogous, but lacks the formal crystallographic centre of symmetry. After (10)

halide ions are weakly associated with the gold atoms, with $\mathrm{Au} . . . \mathrm{Cl}$ (terminal) $=293.7 \mathrm{pm}$ and Au...I (bridging) $=333.0 \mathrm{pm}$. The structures do not explain the observed metallic conductivity.
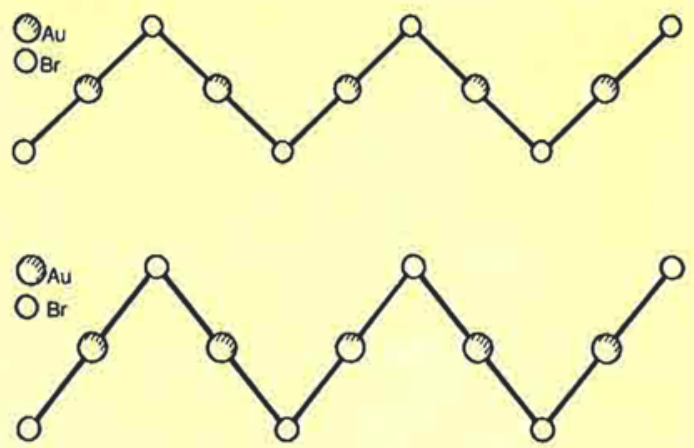

Fig. 7 Gold(I) halide chains, as typified by the two forms of $\mathrm{AuBr}$.

Top: wide $\mathrm{Au}-\mathrm{X}-\mathrm{Au}$ angle form (isostructural with AuCl)

Bottom: narrow Au-X-Au angle form (isostructural with AuI)

Both are drawn to the same scale. After (15a)

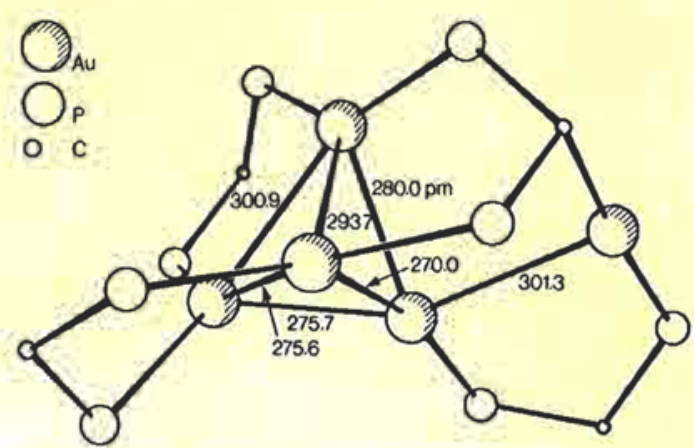

Fig. 8 The $\mathrm{Au}_{5}$ cluster. The phenyl rings are omitted for clarity. After (17)

It has been stated in various reviews that the minerals calaverite and krennerite, both $\mathrm{AuTe}_{2}$, consist of isolated $\mathrm{AuTe}_{2}$ molecules. This is, however, a considerable oversimplification; as was remarked in the original publications $(7,8)$ there are several short $(<320 \mathrm{pm}) \mathrm{Au}-\mathrm{Te}$ contacts for each gold atom.

(Note added in proof: The structure of AuTeI was accidentally omitted from this category. This structure was described by J. Fenner and D. Mootz, J. Solid State Chem., 1978, 24, 367-369.)

\section{Halides and Pseudohalides}

Gold(III) fluoride (9) is a helical fluorine-bridged polymer (Figure 5). The bridging Au-F bonds are, as expected, longer than the terminal ones. Weak crosslinking from chain to chain ( $\mathrm{Au} . . . \mathrm{F}=269 \mathrm{pm}$ ) leads to a highly elongated octahedral geometry about the gold atom.

Gold(III) chloride (10) and bromide (11) are, on the other hand, dimeric molecules without unusually short $\mathrm{Au}$... X contacts. Again, the bridging bonds are longer than the terminal bonds (Figure 6). The adoption of this structure by gold(III) fluoride would 
lead to a very short Au...Au distance; the bridging $\mathrm{X}$-Au-X angles of the chloride and bromide $\left(86^{\circ}\right)$ may be effects of $\mathrm{Au}$...A Au repulsion.

Gold(I) halides have been investigated only by powder methods. These have the advantage that no single crystals need be prepared, but also the disadvantages of overlapping reflexions and difficulty in obtaining accurate intensities. The accuracy of the structure is thus often restricted. Gold(I) chloride $(12,13)$ is a case in point. Although single crystals were available, only powder investigations were carried out. The qualitative structure, a zigzag chain (Figure 7), was easily determined, but the $\mathrm{Cl}$ atoms were positioned by assuming an Au-Cl bond length. The Au-C1-Au angles were then 92 and $94^{\circ}$ in the two determinations. Gold(I) iodide possesses an analogous structure $(14,15)$, but with a much smaller Au-I-Au angle of $72^{\circ}$. Gold(I) bromide (15a) exists in two crystalline forms, isostructural with $\mathrm{AuCl}$ and AuI respectively.

The pseudohalide AuCN has a linear ...-Au-C-NAu-... structure (16nc).

'Gold dichloride' is a mixed Aul-Au ${ }^{\mathrm{III}}$ derivative (see Section IX).

\section{Cluster Compounds*}

The study of transition metal clusters has been one of the most active areas of inorganic chemistry in recent years. X-ray crystallography usually provides the only unambiguous method of structure determination for such compounds; several gold clusters,

* Some very recently published gold cluster structures will be included in a postscript to Part II of this article. for example, have been falsely formulated on the basis of elemental analyses, molecular weight determinations and conductivity data. Gold clusters are given here in ascending order of number of metal atoms.

The $\mathrm{Au}_{5}$ cluster in $\left[\mathrm{Au}_{5}\left(\mathrm{Ph}_{2} \mathrm{PCH}_{2} \mathrm{PPh}_{2}\right)_{3}\right.$ $\left.\left(\mathrm{Ph}_{2} \mathrm{PCHPPh}\right)\right]^{2+}(17)$ consists of an $\mathrm{Au}_{4}$ tetrahedron, the fifth $\mathrm{Au}$ atom being bonded to one atom of this group (Figure 8). Au-Au distances range from 270 to $301 \mathrm{pm}$. One phosphine $\mathrm{CH}_{2}$ group has been deprotonated, an Au-C bond resulting. An unusual feature of this cluster is that three $\mathrm{Au}$ atoms are each coordinated by two P atoms; other clusters show only one Au-P bond per metal atom.

In $\left[\left(\mathrm{Ar}_{3} \mathrm{PAu}\right)_{6}{ }^{2+}\right.$, where $\mathrm{Ar}=p$-tolyl (18), the $\mathrm{Au}_{6}$ core is a somewhat distorted octahedron, with $\mathrm{Au}-\mathrm{Au}$ ranging from 293.2 to $309.1 \mathrm{pm}$.

For the remaining cluster types $\left(\mathrm{Au}_{8}, \mathrm{Au}_{9}, \mathrm{Au}_{11}\right)$ the problem arises of describing the structures in terms of idealized geometry, and of making clear the relationships between them. In one case, independent workers described the same cluster in completely different ways. One unifying feature, which may usefully be mentioned at the outset, is the presence of a central $\mathrm{Au}$ atom $\left(\mathrm{Au}_{\mathrm{c}}\right)$ bonded to all the others; these latter are then described as peripheral $\left(\mathrm{Au}_{\mathrm{p}}\right)$ atoms. $A u_{c}-A u_{p}$ bonds are appreciably shorter than $A u_{p}-A u_{p}$ bonds.

In $\left[\left(\mathrm{Ph}_{3} \mathrm{PAu}\right)_{8}\right]^{2+}$ clusters $(19,20)$ each $\mathrm{Au}$, including $\mathrm{Au}_{\mathrm{c}}$, is bonded to one ligand. Reported bond lengths (those from (20) are in brackets) are: $\mathrm{Au}_{\mathrm{c}}-\mathrm{Au}_{\mathrm{p}}$ $=270.6$ av. (263.5 to 272.3), $\mathrm{Au}_{\mathrm{p}}-\mathrm{Au}_{\mathrm{p}}=287.8$ av. (282.6 to 296.0), $\mathrm{Au}_{\mathrm{p}}-\mathrm{P}=230$ av. (229 to 233) and $A u_{c}-P=238(242) \mathrm{pm}$. The longer $A u_{c}-P$ bond was

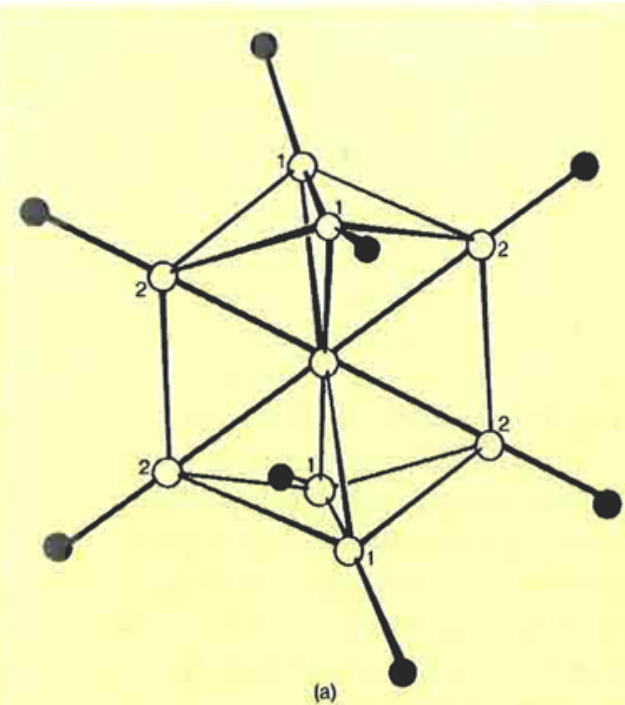

(a)

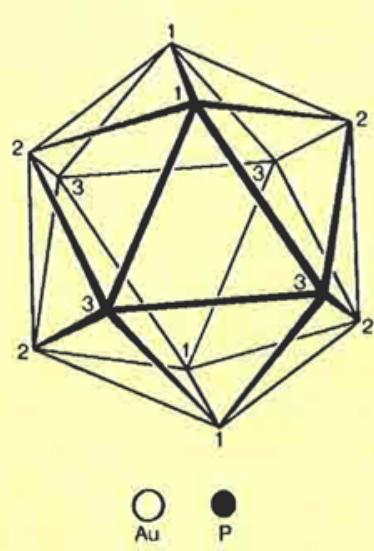

(b)

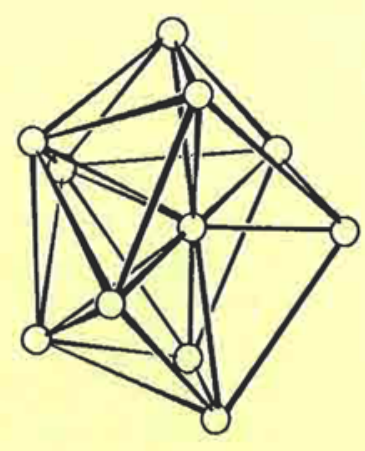

(c)

Fig. 9 Relationships between (a) $\mathrm{Au}_{9}$ and (c) $\mathrm{Au} \mathrm{u}_{11}$ clusters and (b) an ideal icosahedron. The $\mathrm{Au} \mathrm{u}_{9}$ unit is formed from an icosahedron by the removal of the rectangle marked ' 3 ' in (b). The $\mathrm{Au}_{11}$ unit is formed by replacing a triangular face at the extreme right of (b) by a single gold atom. Reproduced with permission from (21) 


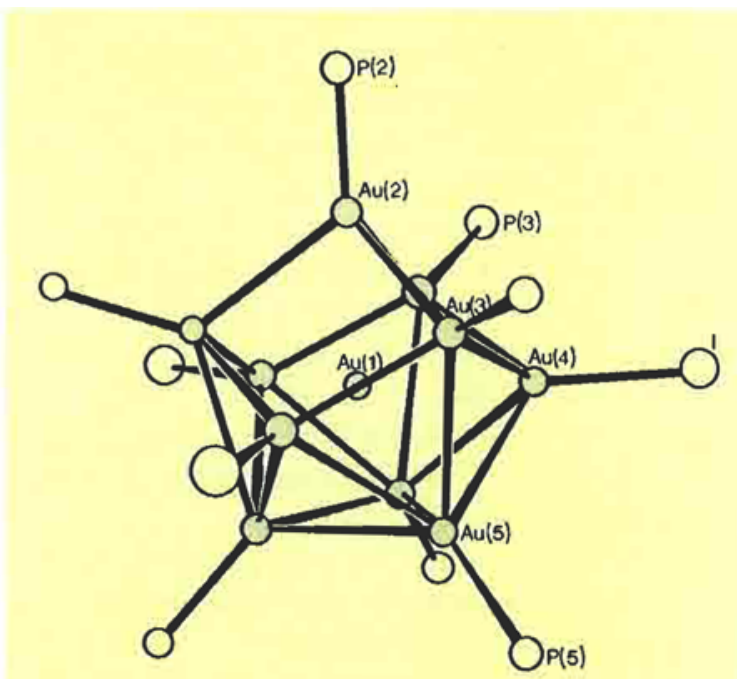

Fig. 10 Detailed structure of $A u_{11}\left(R_{3} P\right)_{7} I_{3}$. Bonds to the central An atom are omitted for clarity. Reproduced with permission from (24)

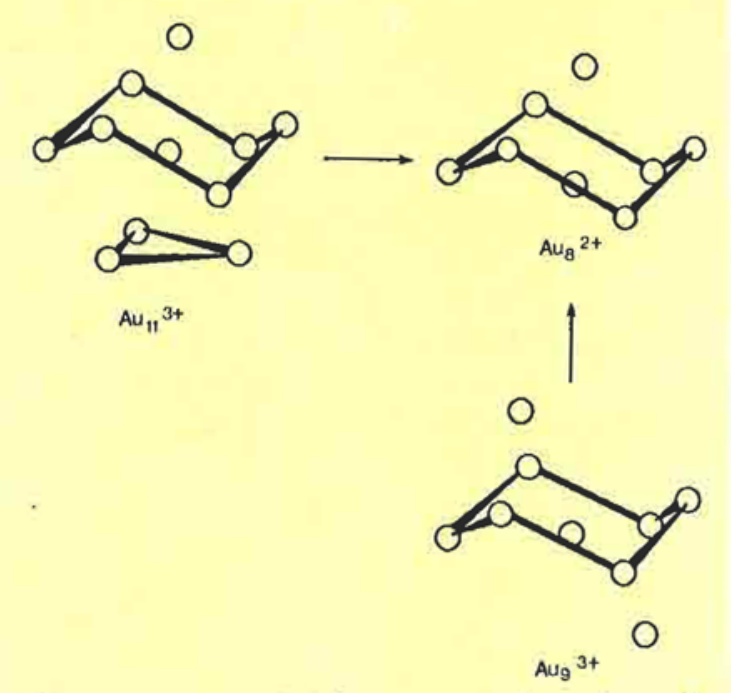

Fig. $11 \mathrm{The}^{\mathrm{Au}} \mathrm{u}_{6}$ 'chair' common to $\mathrm{Au}_{11}, \mathrm{Au}_{9}$ and $\mathrm{Au}_{8}$ clusters. Reproduced with permission from (19)

attributed to the lower availability of bonding orbitals on $\mathrm{Au}_{\mathrm{c}}$. The $\mathrm{Au}_{\mathrm{g}}$ geometry is best described as derived from either an $\mathrm{Au}_{9}$ or $\mathrm{Au}_{\mathrm{UL}}$ unit (see below).

The central atom of the $\left[\mathrm{Au}_{9}\left(\mathrm{Ar}_{3} \mathrm{P}\right)_{8}\right]^{3+}$ cluster $(\mathrm{Ar}$ $=p$-tolyl) $(2 \operatorname{lnc})$ is bonded only to $\mathrm{Au}_{\mathrm{p}}$ atoms, with bond lengths $A u_{c}-A u_{p}=268.9$ to 272.9 and $A u_{p}-A u_{p}$ $=275.2$ to $286.8 \mathrm{pm}$. The cluster possesses crystallographic 222 symmetry; however it does not deviate significantly from $\mathrm{mmm}$ symmetry. The ligands are disordered. (For the non-crystallographer, disorder may loosely be defined as the phenomenon whereby an atom or group does not occupy the same position in each unit cell. This often leads to reduced accuracy in determining atomic positions.) The $\mathrm{Au}_{0}$ core may be regarded as derived from a centered icosahedron by removal of an equatorial rectangle (Figure 9).

$\mathrm{Au}_{11}$ clusters may also best be described as derived from a centered icosahedron, in this case by replacing one triangular face by a single $A u$ atom (Figures 9 and 10). Three such clusters, of general formula $A u_{11}\left(R_{3} P\right)_{7} X_{3}$, have now been investigated with $R=$ $\mathrm{Ph}$ and $\mathrm{X}=\mathrm{SCN}(22 \mathrm{nc}), \mathrm{R}=p-\mathrm{ClC}_{6} \mathrm{H}_{4}$ and $\mathrm{X}=\mathrm{I}$ (23nc), and $\mathrm{R}=p-\mathrm{FC}_{6} \mathrm{H}_{4}$ and $\mathrm{X}=\mathrm{I}(24)$. All possess the same $A u_{11}$ core. Since disorder problems were encountered in determining the structures of the first two, only the third will be discussed further. The molecule possesses crystallographic 3 symmetry (Figure 10). The $A u_{c}-A u_{p}$ distances average $268 \mathrm{pm}$ and the $A u_{p}-A_{p}$ distances are in the range 284 to 319 (av. 298) pm. The iodide ions function as ligands, in contrast to the non-coordinating anions employed in the smaller clusters.

A useful alternative formal description of these clusters, and one which includes the $\mathrm{Au}_{\mathrm{g}}$ cluster, is based on a chair-form 6-membered ring. This structural unit is common to $\mathrm{Au}_{9}, \mathrm{Au}_{9}$ and $\mathrm{Au}_{11}$ clusters (19) (Figure 11).

\section{Compounds with Gold-Transition Metal Bonds}

Gold forms a wide range of compounds containing bonds between gold and transition metals. This occurs predominantly with gold(I) and with transition metal carbonyl derivatives. A number of compounds of general formula $\mathrm{Ph}_{3} \mathrm{PAuX}$ (where $\mathrm{X}$ is the transition metal carbonyl moiety) has been crystallographically investigated, though none with great accuracy. Some distortions from linear coordination are observed (Table I).

The only $M-A u-M$ system to have been studied, the $\left[\mathrm{Au}\{\mathrm{Co}(\mathrm{CO})\}_{4}\right]_{2}^{-}$anion (29), is exactly linear as the gold atom lies on a centre of symmetry. The Au-Co bond length is $250.9 \mathrm{pm}$.

The $\mathrm{Ph}_{3} \mathrm{PAu}$ moiety can also be incorporated into osmium clusters; structures of $\mathrm{Os}_{3}(\mathrm{CO})_{10}\left(\mathrm{Ph}_{3} \mathrm{PAu}\right) \mathrm{X}$ $(\mathrm{X}=\mathrm{Cl}$ or $\mathrm{Br}$ ) have been briefly reported (30nc) (Figure 12). The analogous $\mathrm{X}=\mathrm{SCN}$ and $\mathrm{X}=\mathrm{H}$ structures have also been determined (30a). Au-Os bond lengths are in the range 273 to $277 \mathrm{pm}$.

The complicated cation $\left[\left(\pi-\left(\mathrm{C}_{5} \mathrm{H}_{5}\right) \mathrm{Fe}\left(\pi-\left(\mathrm{C}_{5} \mathrm{H}_{4}\right) \mathrm{Au}_{2}\right.\right.\right.$ $\left.\left(\mathrm{Ph}_{3} \mathrm{P}\right)_{2}\right]^{+}(3 \mathrm{l})$ is shown in Figure 13. One Au atom appears, most unexpectedly, to be bonded to the central iron atom, with $\mathrm{Au}-\mathrm{Fe}=281.8 \mathrm{pm}$, which is somewhat long for a bond from gold to a first row transition metal. In addition, there is an $\mathrm{Au}-\mathrm{Au}$ contact distance of $276.8 \mathrm{pm}$. The C-Au-P angles are $169,174^{\circ}$; although the concept of oxidation state has a purely formal significance in such compounds, this is consistent with formulating both gold atoms as $\mathrm{Au}^{\mathrm{I}}$. Thus, the effects of any $\mathrm{Au}-\mathrm{Fe}$ and $\mathrm{Au}-\mathrm{Au}$ bonding do 
not distort the usual linear coordination at $\mathrm{Au}^{1}$ to any significant extent.

\section{Gold(I) Complexes with Short Au...Au Interactions}

As was noted at the end of the previous Section, an $\mathrm{Au}-\mathrm{Au}$ distance of $276.8 \mathrm{pm}$ is observed in the goldferrocene derivative (31). So many examples of such short (270 to $340 \mathrm{pm}$ ) Au...Au contacts, both interand intramolecular, are now known that they merit a section of this article to themselves. A detailed list of such structures is given below, but a general discussion will initially be useful.

First, what is a 'short' Au...Au contact? Any contact distance of less than about $350 \mathrm{pm}$ is unexpected for such large atoms, while $300 \mathrm{pm}$ or less must rank as 'very short'. It is interesting to compare the following distances: Au...Au in gold metal is $288.4 \mathrm{pm}$ (32), $\mathrm{Au}-\mathrm{Au}$ in gold clusters (which must involve metalmetal bonding) is 260 to $310 \mathrm{pm}$ and $\mathrm{O} \ldots \mathrm{O}$ in hydrogen bonds is mostly in the range 260 to $300 \mathrm{pm}$. If an $\mathrm{O} \ldots \mathrm{O}$ contact of less than $300 \mathrm{pm}$ is regarded as unusually short, what of such an $\mathrm{Au}$...Au contact?

Secondly, can short Au...Au contacts be further classified? A loose distinction may be drawn as follows: (a), compounds with bidentate ligands, or with two gold atoms bonded to a common atom, where the gold atoms are forced to be in close contact (but where one might have anticipated such a contact to prevent the binding of more than one of them) and (b), simple linear complexes in which the gold atoms are unexpectedly close to one another.

Thirdly, can an explanation be given for short Au...Au distances? Many authors have suggested that merely the ease of packing of linear molecules may be responsible, but it is difficult to reconcile this explanation with the wide range of known examples, particularly of class (a) above. It is reasonable to postulate some $\mathrm{Au}-\mathrm{Au}$ bonding interaction for $\mathrm{Au}-\mathrm{Au}$ distances as short as $270 \mathrm{pm}$ since, otherwise, repulsive forces might be expected to predominate. A Raman study of the gold(I) diisobutyldithiocarbamate dimer ( $\mathrm{Au}$...Au $=276 \mathrm{pm}$, see below) has suggested an $\mathrm{Au}-\mathrm{Au}$ bond order of about $1 / 4$, caused by interaction of $6 s$ orbitals into which charge is donated by the ligands (33). It is however difficult to extend this explanation to cover other, rather longer, $\mathrm{Au}$...Au distances, since the strength of the bonding interactions would be expected to die off fairly rapidly with increasing distance. A satisfactory general explanation would also have to take into account that many such $\mathrm{Au} . . \mathrm{Au}$ interactions are almost perpendicular to the ligand-Au-ligand axis, and that they never substantially disturb the linear coordination at $\mathrm{Au}$.

Compounds of class (b) above will be discussed first, since they are simpler and fewer. Molecules of
Table I

Crystallographic Data for $\mathrm{Ph}_{3} \mathbf{P A u X}$ Compounds

\begin{tabular}{c|c|c|c}
\hline $\mathrm{X}$ & $\begin{array}{c}\text { Au-metal } \\
\text { bond } \\
\text { length, } \\
\text { pm }\end{array}$ & $\begin{array}{c}\text { P-Au-M } \\
\text { angle, }\end{array}$ & Reference \\
degrees & \\
\hline $\mathrm{Mn}(\mathrm{CO})_{5}$ & $252(3)$ & $168(1)$ & $25 \mathrm{nc}^{*}$ \\
$\mathrm{Mn}(\mathrm{CO})_{4}\left(\mathrm{P}_{5}\left(\mathrm{Ph}_{3}\right)_{3}\right\}$ & $257(1)$ & $165.51 .1)$ & 26 \\
$\mathrm{~W}(\mathrm{CO})_{3}\left(\mathrm{C}_{5} \mathrm{H}_{5}\right)$ & $269.81 .3)$ & $173.81 .3)$ & 27 \\
$\mathrm{Co}(\mathrm{CO})_{4}$ & $250(1)$ & $177.51 .5)$ & 28
\end{tabular}

-Problems in refinement of data because of pseudosymmetry.

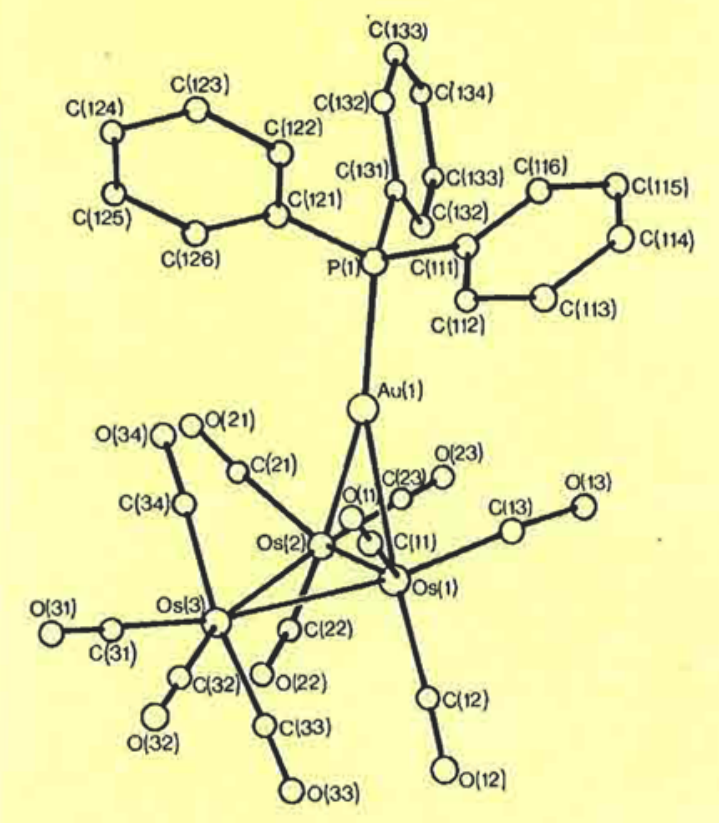

Fig. 12 The structure of $\mathrm{Os}_{3}(\mathrm{CO})_{10}\left(\mathrm{Ph}_{3} \mathrm{PAu}\right) \mathrm{H}$. Note that this structure contains three-coordinate $\mathrm{Au}^{\mathrm{I}}$, although such mixed-metal clusters have been excluded from Section VI of this article. This diagram was kindly provided by Dr. P. R. Raithby

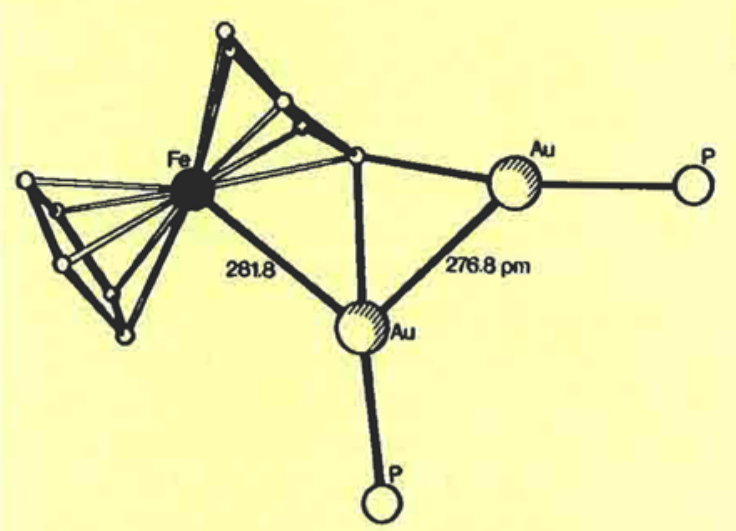

Fig. 13 The unusual cation $\left[\left(\pi-\mathrm{C}_{5} \mathrm{H}_{5}\right) \mathrm{Fe}\left(\pi-\mathrm{C}_{5} \mathrm{H}_{4}\right)\right.$ $\left.\mathrm{Au}_{2}\left(\mathrm{Ph}_{3} \mathrm{P}\right)_{2}\right]^{+}$, which contains an $\mathrm{Au} \cdot \mathrm{Fe}$ bond. The phenyl rings are omitted for clarity. After (31) 


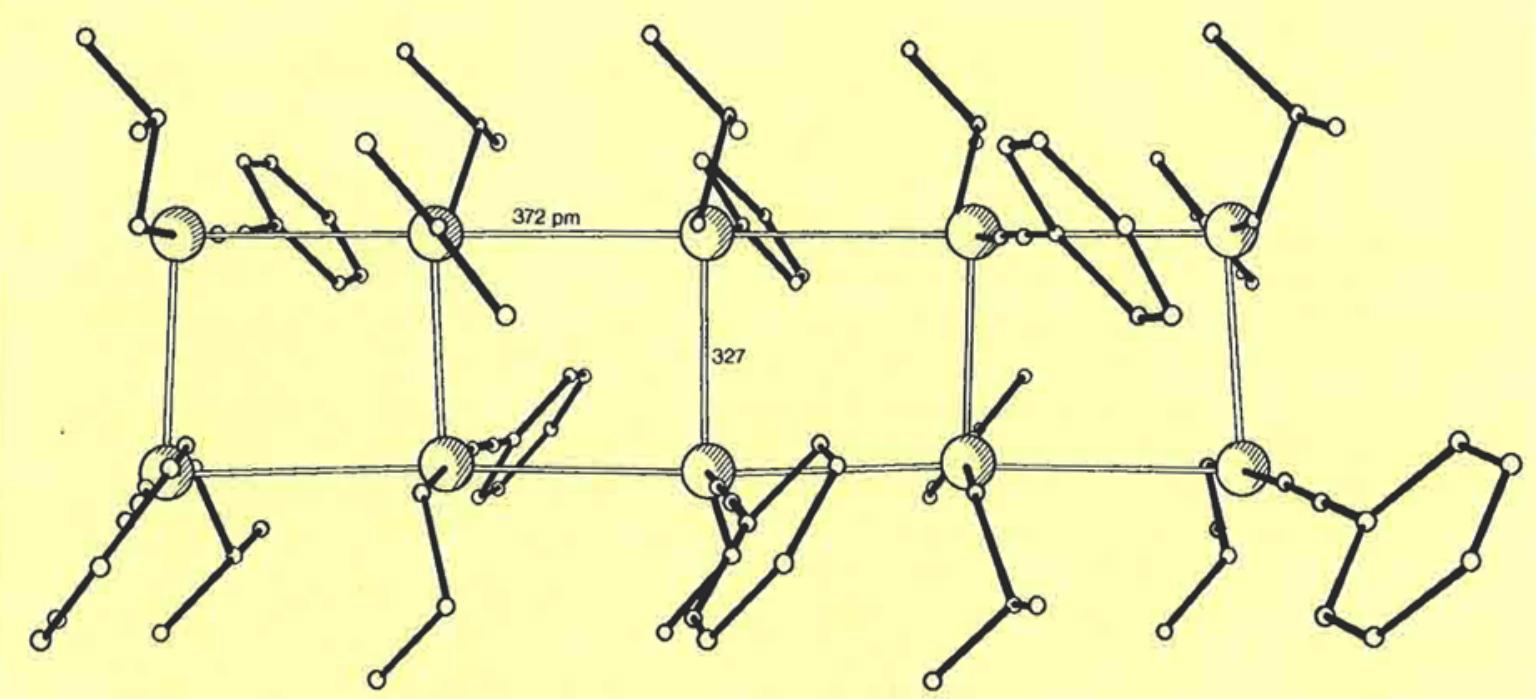

Fig. 14 Part of the $\mathrm{Au}$...Au 'ladder' in $\left(\mathrm{C}_{3} \mathrm{H}_{7} \mathrm{NH}_{2}\right) \mathrm{Au}(\mathrm{C}=\mathrm{CPh})$. After (35)

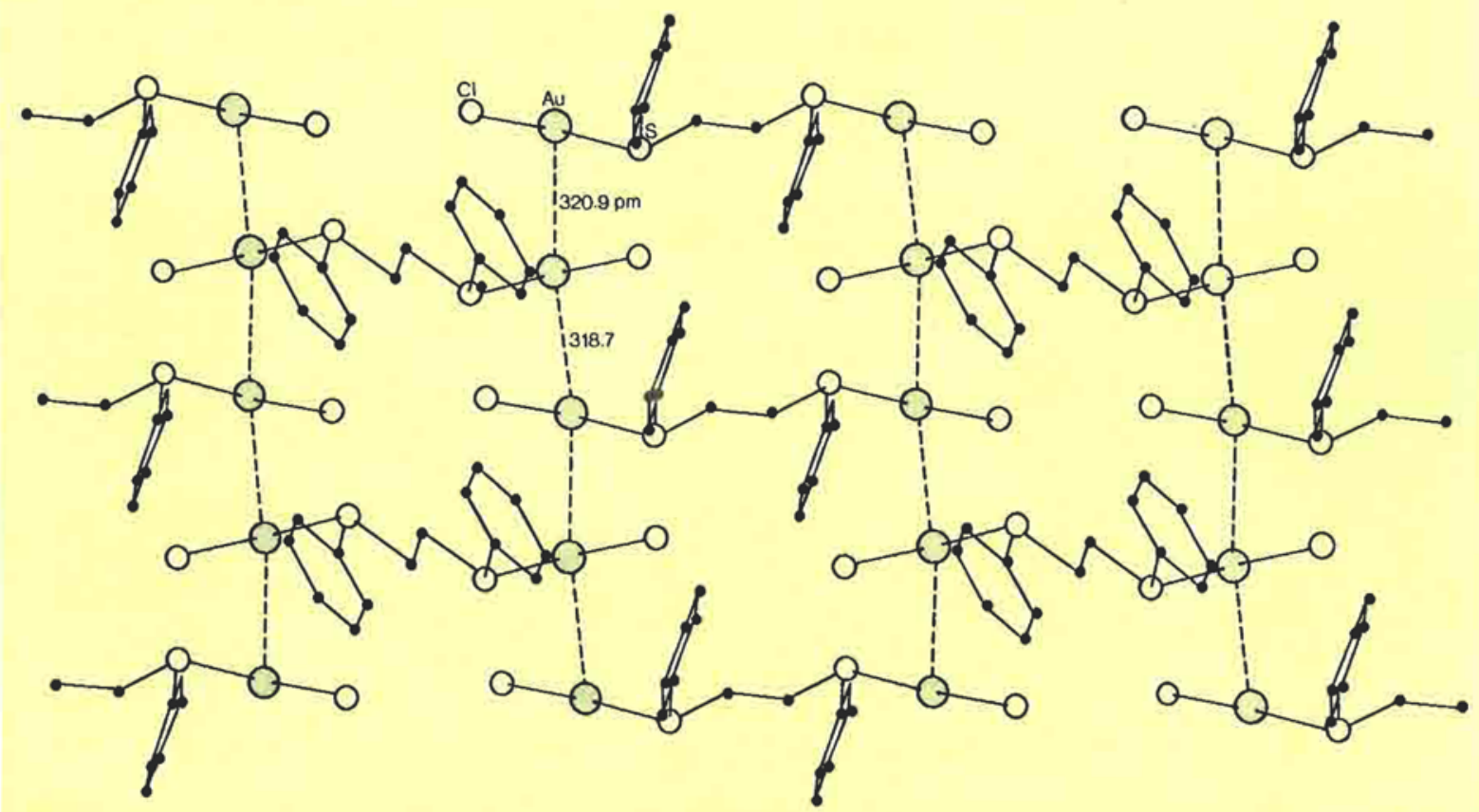

Fig. $15 \mathrm{Au} . . . \mathrm{Au}$ contacts in $\left(\mathrm{C}_{7} \mathrm{H}_{7} \mathrm{SAuCl}\right)_{2}$ projected down the $z$ axis. After.(36)

$\mathrm{Cl}_{3} \mathrm{PAuCl}$ (34) pack so as to form zigzag chains of $\mathrm{Au}$ atoms, with $\mathrm{Au} . . \mathrm{Au}=314 \mathrm{pm}$. (The $\mathrm{Au}-\mathrm{P}$ and $\mathrm{Au}$ $\mathrm{Cl}$ bond lengths given in (34) -219 and $233 \mathrm{pm}$ respectively - do not agree with those calculated from the atomic coordinates and cell constants -218 and $229 \mathrm{pm}$.) In phenylethynyl(isopropylamine)gold(I), $\mathrm{PhC} \equiv \mathrm{CAuNH} \mathrm{C}_{2} \mathrm{H}_{7}$ (35), the molecules are associated in antiparallel pairs with $\mathrm{Au} . . . \mathrm{Au}=327.4$ pm. There are further Au...Au contacts of $372.2 \mathrm{pm}$ between adjacent pairs, forming an infinite twisted ladder of gold atoms (Figure 14). The compound $\mu-[1,2 \cdot b$ is(phenylthio)ethane]-bis[chlorogold(I)], $\left[\mathrm{PhS}(\mathrm{AuCl}) \mathrm{CH}_{2}\right.$ (36), possesses two crystallographically independent centrosymmetric molecules. These display no intramolecular $\mathrm{Au} . . . \mathrm{Au}$ contacts. The packing is, however, such as to produce infinite, almost linear chains of $\mathrm{Au}$ atoms with alternating intermolecular $\mathrm{Au} . . . \mathrm{Au}$ distances of 318.7 and 320.9 pm (Figure 15).

The gold atoms do not always form infinite chains; thus, in (piperidine)AuCl (37) the molecules form loose tetrameric clusters based on a square of gold 

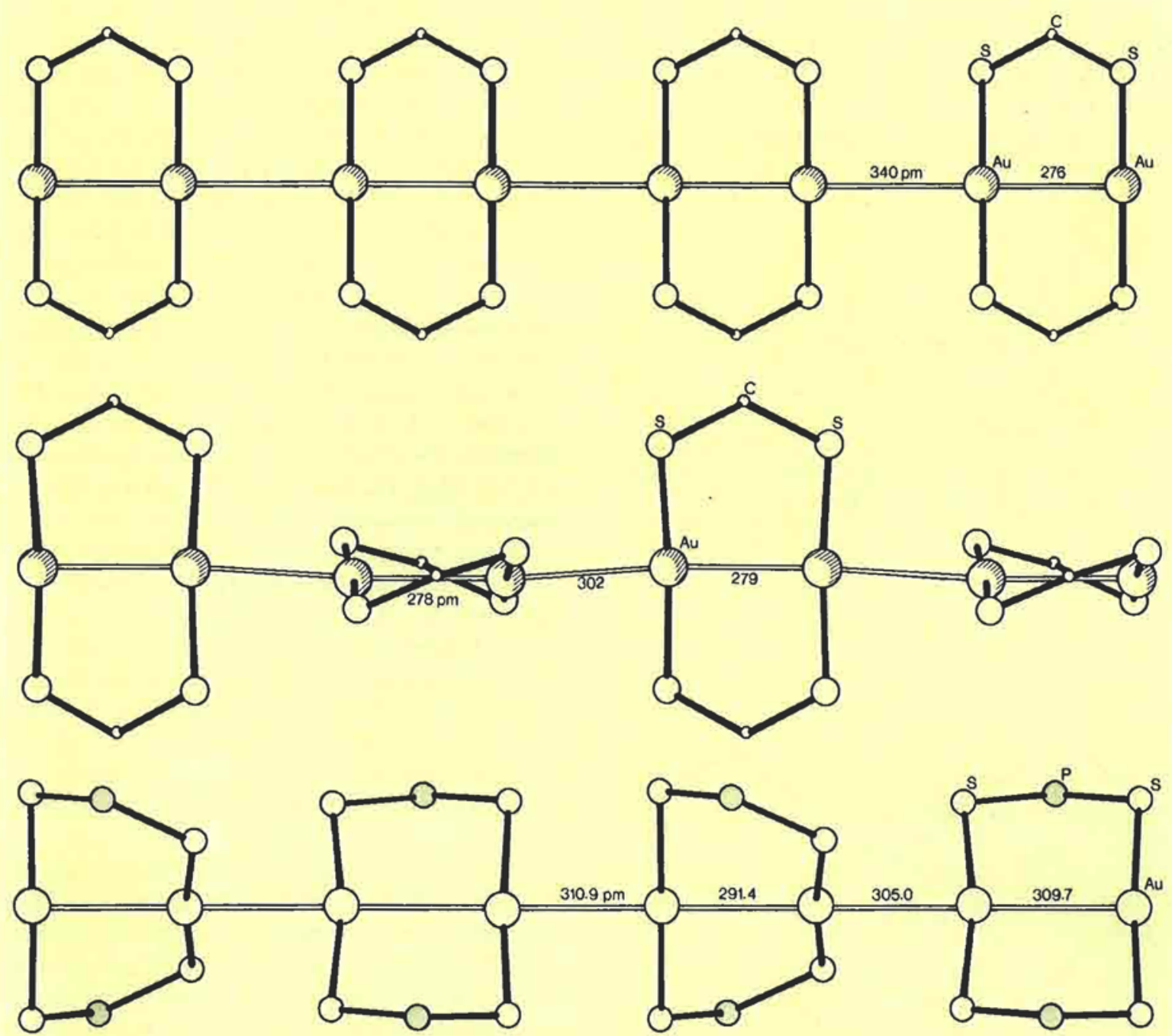

Fig. 16 Au...Au chains in some sulphur complexes.

Top: $\mathbf{R}_{2} \mathrm{NCS}_{2} \mathrm{Au}, \mathbf{R}=n$-propyl. After (41)

Middle: same as (a), but $R=n$-butyl. After (43)

Bottom: $(\mathbf{R O})_{2} \mathbf{P S}_{2} \mathrm{Au}, \mathbf{R}=i$-propyl. After (44)

These projections are perpendicular to the mean planes of the atoms shown and are all to the same scale. The peripheral groups are omitted for clarity. Note that a closer Au...Au approach between dimers, as in (b) and (c), necessitates a twisting apart of adjacent ligands to avoid $\mathrm{S}$...S repulsions

atoms $(\mathrm{Au} . . \mathrm{Au}=330.3 \mathrm{pm})$, and in the thiosulphate complex $\mathrm{Na}_{3}\left[\mathrm{Au}\left(\mathrm{S}_{2} \mathrm{O}_{3}\right)_{2}\right] \mathrm{H}_{2} \mathrm{O}(38,39)$ the anions form centrosymmetrically related pairs with $\mathrm{Au}$...Au $=$ $330.2 \mathrm{pm}$. (Pyridine)chlorogold(I), long formulated simply as pyAuCl, but now shown to be $\left[\mathrm{py}_{2} \mathrm{Au}\right]^{+}\left[\mathrm{AuCl}_{2}\right]^{-}$(37a nc, 37b), displays pairs of cations linked centrosymmetrically with $\mathrm{Au} . . \mathrm{Au}=$ $341.6 \mathrm{pm}$, the $\mathrm{N}-\mathrm{Au}-\mathrm{N}$ groups being correspondingly bent (N-Au-N, $\left.172.5^{\circ}\right)$. The Au atom of each cation is further linked to an $\mathrm{Au}$ atom of $\mathrm{AuCl}_{2}^{-}(\mathrm{Au}$... Au = $324.9 \mathrm{pm}$ ), thus forming zigzag $\mathrm{Au}_{4}$ units.

Compounds of class (a), where two or more gold atoms are brought into close contact by being bonded to common atoms or groups, also comprise a number of types. In some cases such contacts might be regard- ed as unsurprising and as involving insignificant bonding interaction, as is the case with the cis-ethylenic derivative $\left(\mathrm{Ph}_{3} \mathrm{PAu}\right) \mathrm{C}\left(\mathrm{CF}_{3}\right)_{2}$ (40nc), with a rather long Au...Au distance of $334 \mathrm{pm}$. There are however many more striking examples. The gold(I) dithiocarbamates $\mathrm{R}_{2} \mathrm{NCS}_{2} \mathrm{Au}$ ( $\mathrm{R}=n$-propyl (41) or $n$-butyl $(42 \mathrm{nc}, 43)$ form dimers with extremely short $\mathrm{Au} . . . \mathrm{Au}$ distances (276 to $278 \mathrm{pm}$ ). These dimers are then further linked $(\mathrm{Au} . . \mathrm{Au}=340(41), 302(43) \mathrm{pm})$ to form infinite $A u$...Au chains. An identical type of chain is seen in the dithiophosphate complex $\left(i-\mathrm{C}_{3} \mathrm{H}_{7} \mathrm{O}\right)_{2} \mathrm{PS}_{2} \mathrm{Au}(44)$. These compounds are depicted in Figure 16. Gold(I) thioacetate, in contrast, forms tetramers with $\mathrm{Au} . . \mathrm{Au}=301 \mathrm{pm}$ on average (44a nc). 
Bidentate phosphine ligands ('PP') can form compounds of the type $\mathrm{PP}(\mathrm{AuCl})_{2}$ in which the $-\mathrm{AuCl}$ 'arms' might, on purely steric grounds, be expected to rotate away from each other. However, for $\mathrm{PP}=$ $\left(\mathrm{Ph}_{2} \mathrm{P}\right)_{2} \mathrm{CH}_{2}$, which possesses crystallographic 2 sym-

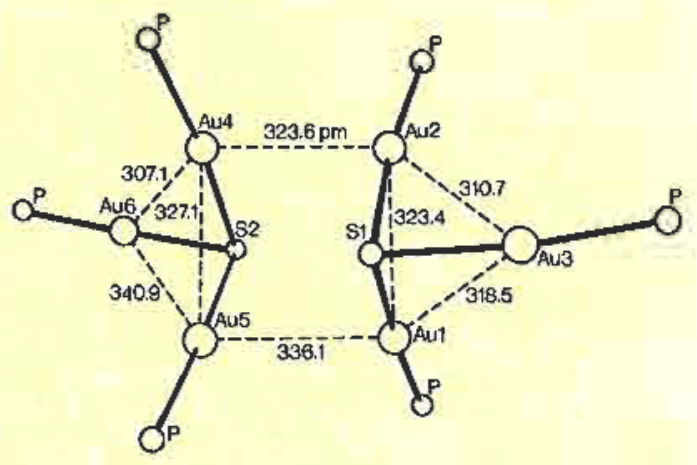

Fig. 17 The $A_{u_{6}} P_{6} S_{2}$ core of $\left[\left(P_{3} P A u\right)_{g} S\right]^{+}$, showing Au...Au contacts. After (48)

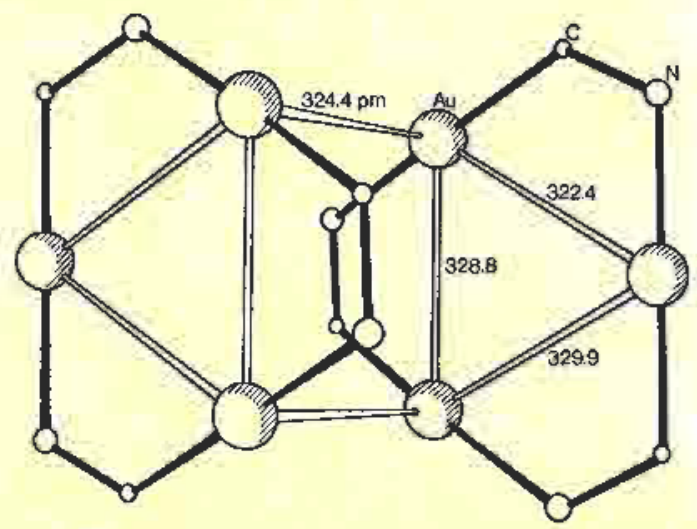

Fig. 18 The Iwo linked 9-membered rings of $[(\mathrm{ArN}=\mathrm{COEt}) \mathrm{Au}]_{3}$, showing Au...Au contacts. The $\mathrm{Au}_{6}$ 'chair' is like that in Figure 17. After (50)

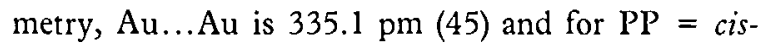
$\mathrm{Ph}_{2} \mathrm{PCHCHPPh}_{2}$ it is $305 \mathrm{pm} \mathrm{(46)}$.

In complexes with bridging mono-atomic anions, the bridged gold atoms are forced to be relatively near each other. They seem, however, to be unexpectedly close in the compound $\left[\left(\mathrm{Ph}_{3} \mathrm{PAu}\right)_{2} \mathrm{Cl}\right]^{+} \mathrm{ClO}_{4}^{-}(47)$. In the two independent cations, the $\mathrm{Au} . . . \mathrm{Au}$ distances are 303.5 and $308.5 \mathrm{pm}$, and the Au-Cl-Au angles 80.7 and $82.7^{\circ}$, which is appreciably less than would be expected for $p$ bonding. In the related sulphur derivative $\left[\left(\mathrm{Ph}_{3} \mathrm{PAu}\right)_{3} \mathrm{~S}\right]^{+} \mathrm{PF}_{6}^{-}(48)$ there are again two independent cations, but the situation is more complicated. One cation shows low Au-S-Au angles (87.6, 86.4 and $83.4^{\circ}$ ) and correspondingly short $\mathrm{Au} . . \mathrm{Au}$ distances $(323.4,318.3$ and $310.6 \mathrm{pm})$, the other only one low angle $\left(82.8,89.1\right.$ and $\left.94.9^{\circ}\right)$ and $\mathrm{Au} . . \mathrm{Au}$ contacts of $327.2,307.0$ and $340.8 \mathrm{pm}$. The cations are linked in pairs (Figure 17) by Au...Au contacts of 336.1 and $323.8 \mathrm{pm}$, forming an $\mathrm{Au}_{6}$ ring with 'chair' conformation which is strikingly reminiscent of the $\mathrm{Au}_{6}$ ring common to several clusters (see Section II).

The zigzag chains of $\mathrm{AuI}(14,15)$, the isostructural $\mathrm{AuBr}(15 \mathrm{a})$ and the isoelectronic $\mathrm{AuSb}^{2-}$ and $\mathrm{AuAs}^{2-}$ (1a) furnish further examples of close $\mathrm{Au}$...Au contacts between bridged gold atoms; zigzag angles of 67 to $77^{\circ}$ are reflected in $\mathrm{Au}$...Au distances of 288 to $308 \mathrm{pm}$.

Several cyclic complexes show transannular Au...Au contacts. Thus, the mixed $\mathrm{Au}^{\mathrm{I}}-\mathrm{Au}^{\mathrm{III}}$ derivative ' $\mathrm{AuCl}_{2}$ ' (49nc) (see Section IX) contains $\mathrm{Au}_{4} \mathrm{Cl}_{4}$ rings with $\mathrm{Au}^{\mathrm{I}} \ldots \mathrm{Au}^{\mathrm{I}}=309.5 \mathrm{pm}$, and the trimer $[(\mathrm{ArN}=\mathrm{COEt}) \mathrm{Au}]_{3}(\mathrm{Ar}=p$-tolyl) $(50)$ (Figure 18) possesses 9 -membered rings with $\mathrm{Au} . . \mathrm{Au}=$ $324.4,328.8$ and $329.9 \mathrm{pm}$. These latter distances are, perhaps not suprisingly, short for Au atoms constrained by ring geometry; however, the molecules are further linked in pairs ( $\mathrm{Au} . . . \mathrm{Au}=324.4 \mathrm{pm})$,

Table II

Bond Lengths in $\mathrm{AuX}_{2}^{-}$Ions

\begin{tabular}{|c|c|c|c|c|}
\hline$x$ & Compound & $\begin{array}{c}\text { Au-X } \\
\text { bond length, } \\
\text { pm }\end{array}$ & Comments & References \\
\hline $\begin{array}{l}\mathrm{Cl} \\
\mathrm{Cl} \\
\mathrm{Cl} \\
\mathrm{Br} \\
\mathrm{Br} \\
\mathrm{I} \\
\mathrm{I} \\
\mathrm{Br}\end{array}$ & $\begin{array}{c}\mathrm{py}_{2} \mathrm{Au}^{+} \mathrm{AuCl}_{2}^{-} \\
\mathrm{Cs}_{2} \mathrm{Au}_{2} \mathrm{Cl}_{6} \\
\mathrm{Rb}_{3} \mathrm{Au}_{3} \mathrm{Cl}_{8} \\
\left\langle\mathrm{dtcl}_{2} \mathrm{Au}^{+} \mathrm{AuBr}_{2}^{-}\right. \\
\mathrm{Rb}_{2} \mathrm{Au}_{2} \mathrm{Br}_{6} \\
\mathrm{Rb}_{2} \mathrm{AgAu}_{3} \mathrm{I}_{8} \\
\mathrm{~K}_{2} \mathrm{Au}_{2} \mathrm{I}_{6} \\
\mathrm{Cs}_{2} \mathrm{Ag}_{\mathrm{x}} \mathrm{Au}_{2-\mathrm{x}} \mathrm{Br}_{6}\end{array}$ & $\begin{array}{c}229.3(1.5), 226.0(1.4) \\
228.1(.2) \\
228,229(3) \\
234.9(.5) \\
240.2(.8) \\
257.0(.9), 254.9(.9) \\
256.4(.3) \\
\text { approx. } 240\end{array}$ & $\begin{array}{c}\text { short } \mathrm{Au} . . . \mathrm{Au} \\
4 / \mathrm{mmm}^{*} \\
\text { short } \mathrm{Au} . . \mathrm{Au} \\
\text { at }-150^{\circ} \mathrm{C} ; \overline{7}^{*}, * * \\
2 / \mathrm{m}^{*} \\
\text { short } \mathrm{Au} . . \mathrm{Au} \\
7^{*} \\
\text { statistically disordered }\end{array}$ & $\begin{array}{c}37 \mathrm{anc}, 37 \mathrm{~b} \\
61 \\
57 \\
62 \\
57 \\
58 \\
63 \\
63\end{array}$ \\
\hline
\end{tabular}


which implies some weak interaction over this distance. More examples are provided by the 8-membered rings shown in Figure 19 (51, 52, 52a, $53 \mathrm{nc}, 54 \mathrm{nc}, 55,56)$. In (5l) the S-Au-P angle of $173.5^{\circ}$ is adduced as evidence for an $\mathrm{Au} . . . \mathrm{Au}$ interaction, since the deviation from linearity is such as to bring the atoms closer. Unfortunately, in (53) the distortion (C-Au-C 166, $171^{\circ}$, in two independent molecules) causes the $\mathrm{Au}$ atoms to be farther apart than would otherwise be the case, so a generalization is again impossible. Sixfold disorder of $\mathrm{Au}$ atoms is described in (54), only four of the possible six $S$ atoms being bridged in each disorder component. A rare example of three-coordinate $\mathrm{Au}^{\mathrm{I}}$ (see Section VI) is reported in (55), in which the P-Au-P angle of $155.9^{\circ}$ can perhaps better be attributed to the effect of a (rather long) Au-Cl bond than to any appreciable $\mathrm{Au} . . \mathrm{Au}$ interaction. In $\mathrm{Au}_{2} \mathrm{BaSnS}_{4}$ (56), chains of $\mathrm{SnS}_{4}^{4-}$ tetrahedra are linked by $\mathrm{S}-\mathrm{Au}-\mathrm{S}$ bridges.

The complicated gold phosphides already mentioned (1) display a number of (unclassifiable) short $\mathrm{Au}^{\mathrm{I}}$...Au ${ }^{\mathrm{l}}$ distances (293.2 to $313.6 \mathrm{pm}$ ). The metallic conductivity of the compounds has been attributed to these interactions.

Finally, some mixed-valence gold compounds (see Section IX) show short Au...Au distances. Thus, $\mathrm{Rb}_{3} \mathrm{Au}_{3} \mathrm{Cl}_{8}$ (57) contains adjacent $\mathrm{AuCl}_{2}^{-}$ions with $\mathrm{Au} . . \mathrm{Au}=323 \mathrm{pm}$, and $\mathrm{Rb}_{2} \mathrm{AgAu}_{3} \mathrm{I}_{8}$ (58) contains $\mathrm{AuI}_{2}^{-}$ions with $\mathrm{Au}$...Au $=303.7 \mathrm{pm}$. The compound $\left[\mathrm{DMG}_{2} \mathrm{Au}\right]+\left[\mathrm{AuCl}_{2}\right]^{-}$(59) (DMG = dimethylglyoxime; only Au atoms located) contains the only known example of a short $\mathrm{Au}^{\mathrm{I}}-\mathrm{A} \mathrm{u}^{\mathrm{III}}$ contact $(326 \mathrm{pm})$.

\section{Other Linear Gold(I) Complexes Halides}

An $\mathrm{AuCl}_{2}^{-}$derivative was studied in 1954 , but only the $\mathrm{Au}$ atoms were located (59). The $3,3^{\prime}$-diethylcarbocyanin salt of the same anion has also been investigated with limited accuracy (60); the $\mathrm{Au}-\mathrm{Cl}$ bond lengths were 229(2) and 231(1) pm. More accurate values for $\mathrm{AuX}_{2}^{-}$ions were available, mainly from studies of mixed-valence compounds (see Table II and Section IX).

The appreciable difference in $\mathrm{Au}-\mathrm{Br}$ bond lengths of the two $\mathrm{AuBr}_{2}^{-}$determinations reported in Table II is not easily explained.

Fig. 19 Some examples of short Au...Au contacts across 8-membered rings.

(a) $\left[\mathrm{AuSCH}_{2} \mathrm{CH}_{2} \mathrm{PEt}_{2}\right]_{2}$. After (51)

(b) to (h), line diagrams (not geometrically accurate) of similar structures established in (52), (52a), (53), (54), (163), (56) and (55) respectively. The compound studied in (163) is formally an $\mathrm{Au}^{\mathrm{II}}$ derivative. See also Figures 21 and 29

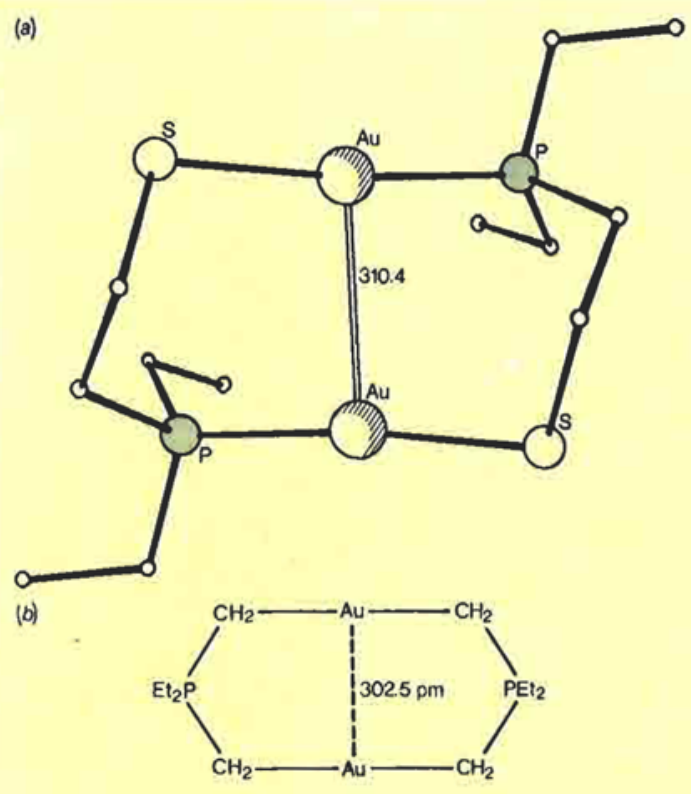

(c)
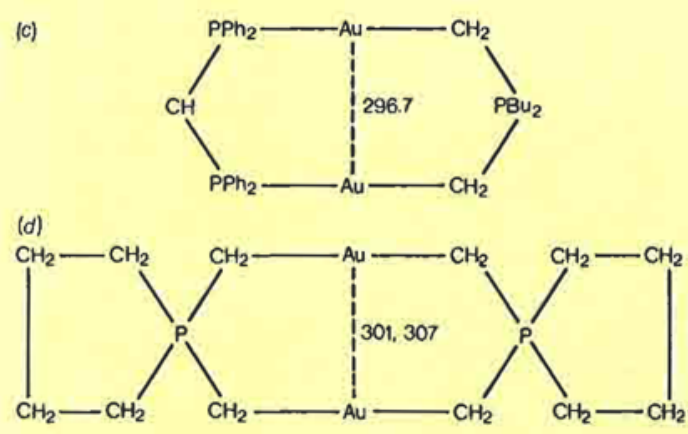

(e)

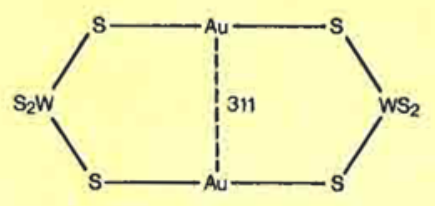

(l)
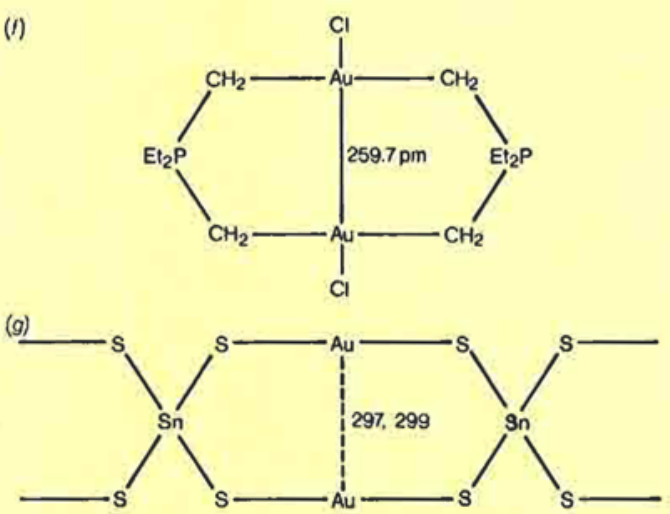

(h)

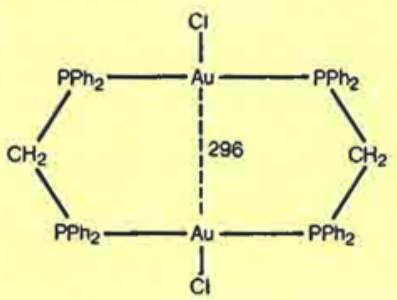


Table III

$A u^{1}-N$ Bond Lengths

\begin{tabular}{|c|c|c|c|}
\hline Compound & $\begin{array}{c}\text { Au-N } \\
\text { bond length, } \\
\text { pm }\end{array}$ & Comments & References \\
\hline $\begin{array}{c}\left(\mathrm{C}_{3} \mathrm{H}_{7} \mathrm{NH}_{2}\right) \mathrm{AuC} \equiv \mathrm{CPh} \\
(\text { piperidine }) \mathrm{AuCl} \\
{[(\mathrm{ArN}=\mathrm{COEt})] \mathrm{Au}_{3}} \\
{\left[\mathrm{py}{ }_{2}^{\mathrm{Au}]}\left[\mathrm{AuCl}_{2}\right]\right.} \\
\left.\left[\mathrm{MeN} . \mathrm{CO} . \mathrm{N} . \mathrm{CO} . \mathrm{CH}_{2}\right)_{2} \mathrm{Au}^{-}\right]-\mathrm{Na}^{+} \cdot 4 \mathrm{H}_{2} \mathrm{O}\end{array}$ & $\begin{array}{c}203(1) \\
206.8(1.8) \\
201.8(2.2), 203.7(2.3) \\
204.5(2.1) \\
207.6(3.4), 209.7(3.8) \\
194 \text { (av.) }\end{array}$ & $\begin{array}{l}\text { short } \mathrm{Au} . . . \mathrm{Au} \\
\text { short } \mathrm{Au} . . \mathrm{Au} \\
\text { short } \mathrm{Au} . . \mathrm{Au} \text { (Figure 18) } \\
\text { short Au...A Au, at }-80^{\circ} \mathrm{C} \\
2 \text { ions with } \bar{T} \text { symmetry }\end{array}$ & $\begin{array}{c}35 \\
37 \\
50 \\
37 \mathrm{a} \text { nc, } 37 \mathrm{~b} \\
65\end{array}$ \\
\hline
\end{tabular}

Other halogen complexes (of the form LAuX) will be found under the appropriate $\mathrm{L}$ heading.

\section{Oxides}

Gold(I) forms very few compounds with Au-O bonds; only one crystallographic investigation has been carried out. Powder diagrams of the oxaurate $\mathrm{CsAuO}$ have shown (64) that it possesses an analogous structure to $\mathrm{KAgO}$, and hence contains $\mathrm{Au}_{4} \mathrm{O}_{4}^{4-}$ units.

\section{Compounds with Nitrogen Ligands}

Being a typical class $b$ metal, gold(I) shows a much greater tendency to form complexes with $S$ and $P$ than with $\mathrm{O}$ and $\mathrm{N}$ ligands. A correspondingly small number of $\mathrm{N}$-donor complexes has been structurally investigated. Although the light atom positions (and hence $\mathrm{Au}-\mathrm{N}$ bond lengths) are of limited accuracy in the presence of gold, the Au-N bond length seems not very sensitive to the nature of the ligands (Table III). An exception is the bis-hydantoin derivative (65) with short Au-N bonds (194 pm).

As mentioned in the previous Section, 'pyAuCl' has suprisingly been shown (37a nc, 37b) to consist of $\mathrm{py}_{2} \mathrm{Au}^{+}$and $\mathrm{AuCl}_{2}^{-}$ions. It is the only $\mathrm{LAuCl}$ compound known to possess this structure and is an interesting contrast to (piperidine) $\mathrm{AuCl}$ (37).

\section{Organogold(I) Derivatives}

Gold(I) forms a variety of compounds containing Au-C bonds. Again, the problem of inaccurate light atom positions is encountered.

In cyanides and related complexes the Au-C bond length is fairly constant at around $200 \mathrm{pm}$ (see Table IV). An exception is $\mathrm{Ph}_{3} \mathrm{PAuCN}$ (66nc) which also shows some deviations from linearity (Au-C-N,

Table IV

Au'-C Bond Lengths

\begin{tabular}{|c|c|c|c|}
\hline Compound & $\begin{array}{c}\text { Au-C } \\
\text { bond length, } \\
\text { pm }\end{array}$ & Comments & Reference \\
\hline 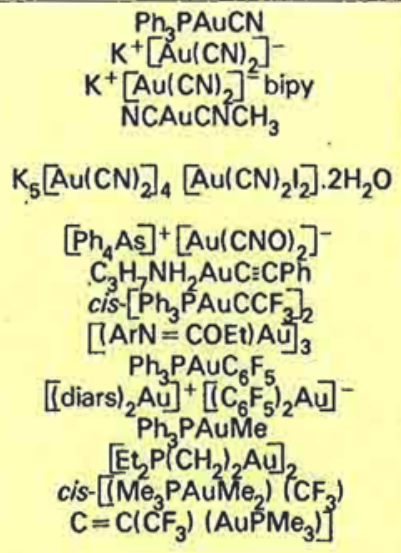 & 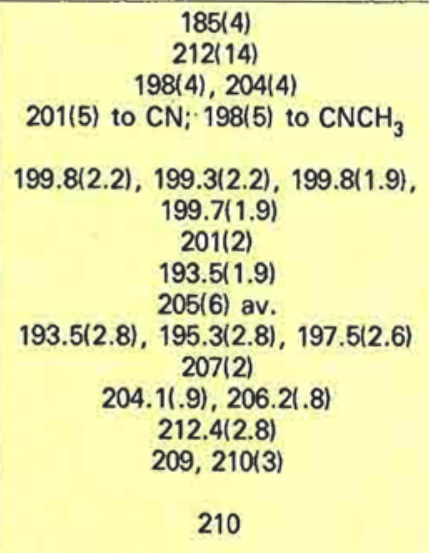 & $\begin{array}{c}F^{*} \\
\text { pseudosymmetric } \\
m^{*} \text {; entire molecule } \\
\text { lies on mirror plane } \\
\text { mixed valence } \\
\text { F } \\
\text { short Au...Au } \\
\text { pseudosymmetric } \\
\text { short Au...Au } \\
F^{*} \text {; two indep. anions } \\
F^{*} \text {; Figure 19(b) } \\
\text { mixed valence }\end{array}$ & $\begin{array}{c}66 \mathrm{nc} \\
67 \\
69 \\
70 \\
\text { Sect. IX } \\
71 \\
35 \\
40 \mathrm{nc} \\
50 \\
72 \\
73 \\
74 \\
52 \\
74 \mathrm{a} \mathrm{nc}\end{array}$ \\
\hline
\end{tabular}

"Au atom on, or related through, special positions with this symmetry. 
$163(4)^{\circ}$ and $\left.\mathrm{P}-\mathrm{Au}-\mathrm{C}, 169(2)^{\circ}\right)$. Exact linearity at $\mathrm{Au}$ is observed in $\mathrm{K}^{+}\left[\mathrm{Au}(\mathrm{CN})_{2}\right]^{-}(67)$. Its $1: 1$ addition product with 2,2'-bipyridyl was reported (68), from packing considerations imposed by a very short axis, to contain square-planar coordinated $\mathrm{Au}^{1}$, a most unexpected geometry. It has now been shown (69) that a false space group had been assigned and that the structure consists of $\mathrm{Au}(\mathrm{CN})_{2}^{-}$ions and of bipyridyl coordinated only to $\mathrm{K}^{+}$. (Methylisocyanide)cyano$\operatorname{gold}(\mathrm{I})$, an unexpected product of the reaction between $\mathrm{MeI}$ and $\left[\mathrm{Ph}_{4} \mathrm{As}\right]+\left[\mathrm{Au}(\mathrm{CN})_{2}\right]^{-}$, consists of linear molecules which pack parallel to each other, the gold atoms lying in two-dimensional layers with $\mathrm{Au}$... Au $=352$ to $372 \mathrm{pm}(70)$. The dicyanatogold(I) anion also called difulminatogold(I) - has been shown, by the linearity of the M-C-N moiety, to possess Au-C rather than $\mathrm{Au}-\mathrm{O}$ bonds (71). $\mathrm{C}$ and $\mathrm{O}$ would otherwise be extremely difficult to distinguish using $\mathrm{X}$-ray methods. The $\mathrm{Au}-s p \mathrm{C}$ bond in $\mathrm{C}_{3} \mathrm{H}_{7} \mathrm{NH}_{2} \mathrm{AuC}=\mathrm{CPh}$ (35) is rather short (193.5(15) pm).

Several examples of $\mathrm{Au}^{\mathrm{I}}$ bonded to $s p^{2} \mathrm{C}$ are known; cis-[ $\left[\mathrm{Ph}_{3} \mathrm{PAuCCF}_{3_{2}}\right]_{2}(40 \mathrm{nc})$ is a rare example of $\sigma$-bonding between an ethylenic moiety and a transition metal. A similar system, but with $\mathrm{C}=\mathrm{N}$ bonds, is the trimer $[(\mathrm{ArN}=\mathrm{COEt}) \mathrm{Au}]_{3}(50)$ (Figure 18). Two perfluorophenyl derivatives have been studied; in $\mathrm{Ph}_{3} \mathrm{PAuC}_{6} \mathrm{~F}_{5}$ (72) and $\left[\left(\mathrm{C}_{6} \mathrm{~F}_{5}\right)_{2} \mathrm{Au}\right]^{-}$(73) the $\mathrm{Au}-\mathrm{C}$ bond lengths are not significantly different.

For compounds in which gold is bonded to an $s p$ or $s p^{2} \mathrm{C}$ atom, some $p \pi d \pi$ bonding is theoretically possible. If extensive, this should be reflected in a shortening of the $\mathrm{Au}-\mathrm{C}$ bond relative to $\mathrm{Au}-s \mathrm{p}^{3} \mathrm{C}$ (over and above the shortening of about 3 pm caused by change in hybridization of C). There are, however, few such $s p^{3} \mathrm{C}$ structures available for comparison. In the simple alkyl derivative $\mathrm{Ph}_{3} \mathrm{PAuMe}(74)$ the $\mathrm{Au}-\mathrm{C}$ bond length is $212.4(28) \mathrm{pm}$, in a phosphorus ylid complex (Figure 19b) it is 209, 210(3) pm (52). (An ylid is a sulphur or phosphorus compound with bonds to carbon representable either as $\mathrm{X}=\mathrm{C}$ or $\mathrm{X}^{+}-\mathrm{C}^{-}$.) A further ylid has been studied (Figure 19d) (53nc), but no $\mathrm{Au}-\mathrm{C}$ bond lengths were given. The mixed $\mathrm{Au}^{\mathrm{I}}-\mathrm{Au}^{\mathrm{III}}$ compound cis-[( $\left.\mathrm{Me}_{3} \mathrm{PAuMe}_{2}\right)\left(\mathrm{CF}_{3}\right) \mathrm{C}=\mathrm{C}\left(\mathrm{CF}_{3}\right)$ $\left.\left(\mathrm{AuPMe}_{3}\right)\right](74 \mathrm{a} \mathrm{nc})$ has $\mathrm{Au}^{\mathrm{I}}-\mathrm{C}=210 \mathrm{pm}$. From Table IV it can be seen that a shortening of the $\mathrm{Au}-\mathrm{C}$ bond is observed for potentially $p \pi d \pi$ bonding systems, and therefore that this type of bonding probably occurs to an appreciable extent. This is however in conflict with conclusions from Mössbauer spectroscopy $(74 b)$.

\section{Compounds with Sulphur Ligands}

Several such complexes have already been mentioned in Section IV; in particular, complexes of bidentate sulphur ligands tend to possess short $\mathrm{Au} . . \mathrm{Au}$ distances. Where the only bonds to gold are from sulphur, their length is remarkably constant at about $228 \mathrm{pm}(38,39,41,43,44)$; the exceptions occur when the gold atoms are disordered, leading to the wider ranges of 229.2 to $241.4 \mathrm{pm}$ in $\left[\mathrm{Au}_{2}\left(\mathrm{WS}_{4}\right)_{2}\right]^{2-}$ (54nc) and 217 to $237 \mathrm{pm}$ in $\mathrm{Au}_{2} \mathrm{BaSnS}_{4}(56)$. The $\mathrm{Au}$ atom in $\left[(\mathrm{etu})_{2} \mathrm{Au}\right]^{+} \mathrm{Cl}^{-}$(75) (etu = ethylenethiourea) has been shown to be two-coordinate with uncoordinated chloride ion, underlining the tendency of $\mathrm{Au}^{\mathrm{I}}$ to two-coordination. The molecule shows typical Au-S bond lengths, but is bent at Au (S-Au-S, $\left.167.2^{\circ}\right)$, probably to accommodate the water molecule which bridges the ligands by hydrogen bonding (Figure 20). The dithiocarbamate (dtc) complex $\mathrm{Ph}_{3} \mathrm{PAu}\left(\mathrm{S}_{2} \mathrm{CNEt}_{2}\right)(76)$ is also two-coordinate, despite the usually chelating dtc ligand; the Au-S bond length is $233.8 \mathrm{pm}$. The other $\mathrm{S}$ atom is too far from the $\mathrm{Au}$ atom to be involved in significant bonding interactions, as is reflected in the C-S distances (168 and 175 $\mathrm{pm}$ to the non-coordinated and coordinated $S$ atoms respectively). There is however some deviation from linearity at $\mathrm{Au}\left(\mathrm{P}-\mathrm{Au}-\mathrm{S}, 175.7^{\circ}\right)$. It is interesting to compare this compound with the tetrathiosquarate described in Section VI. Au-S bond lengths trans to P are somewhat longer than when trans to $\mathrm{S}$, as seen in the formally $\mathrm{RS}^{-}$and $\mathrm{S}^{2-}$ complexes $\left[\mathrm{Et}_{2} \mathrm{PCH}_{2} \mathrm{SAu}_{2}\right.$ (51) and $\left[\left(\mathrm{Ph}_{3} \mathrm{PAu}\right)_{3} \mathrm{~S}\right]^{+} \mathrm{PF}_{6}^{-}(48)(\mathrm{Au}-\mathrm{S}=231$ and 230.3 to $234.2 \mathrm{pm}$ respectively). Au-S bond lengths trans to $\mathrm{Cl}$, on the other hand, are short; $\left[\mathrm{ClAuSCH}_{2} \mathrm{Ph}\right]_{2}(36)$ has Au-S $=226 \mathrm{pm}$ on average. It is perhaps surprising that a wider range of S-Au complexes has not been studied.

\section{Complexes with Phosphorus or Arsenic Ligands}

Gold(I) forms a wide range of compounds with tertiary phosphine ligands, and a correspondingly large number of structures has been reported. This leads to the possibility that bond lengths in a series of related compounds could be correlated with assumed trends in electronic structure. Table Va shows bond lengths

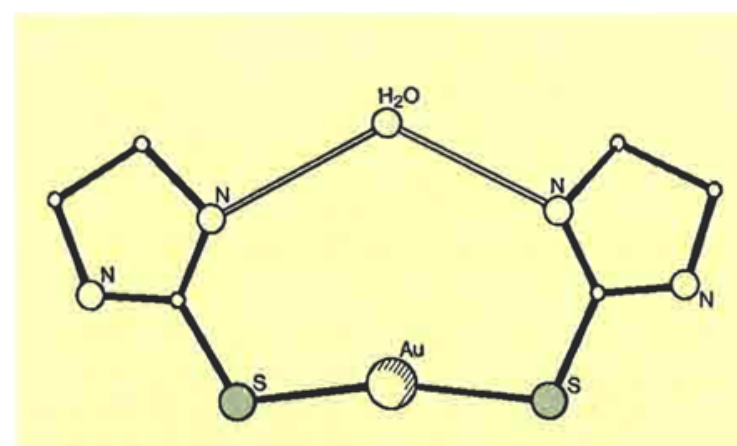

Fig. 20 The bis(ethylenethiourea) gold(I) cation, showing the distortion from linearity and the hydrogen bonding to the water of crystallization (open bonds). After (75) 
Table V

(a) Bond Lengths in Some $\mathbf{R}_{3}$ PAuCl Species

\begin{tabular}{|c|c|c|c|c|}
\hline Compound & $\begin{array}{c}\text { Au-P } \\
\text { bond length, } \\
\text { pm }\end{array}$ & $\begin{array}{c}\mathrm{Au}-\mathrm{Cl} \\
\text { bond length, } \\
\mathrm{pm}\end{array}$ & Comments & Reference \\
\hline $\begin{array}{c}\mathrm{Ph}_{3} \mathrm{PAuCl} \\
(\mathrm{PhO})_{3} \mathrm{PAuCl} \\
\mathrm{Cl}_{3} \mathrm{PAuCl} \\
{\left[\left(\mathrm{Ph}_{3} \mathrm{PAu}_{2} \mathrm{Cl}\right]^{+} \mathrm{ClO}_{4}\right.}\end{array}$ & $\begin{array}{c}223.5(.3) \\
219.2(.5) \\
219 \\
223.0(.5), 223.9(.4)\end{array}$ & $\begin{array}{c}227.9(.3) \\
227.3(.5) \\
229 \\
232.8(.5), 234.0(.5)\end{array}$ & $\begin{array}{c}\text { not refined } \\
\text { two indep. cations }\end{array}$ & $\begin{array}{l}78 \\
77 \\
34 \\
47\end{array}$ \\
\hline
\end{tabular}

(b) Bond Lengths in Some $\mathrm{Ph}_{3}$ PAuX Species

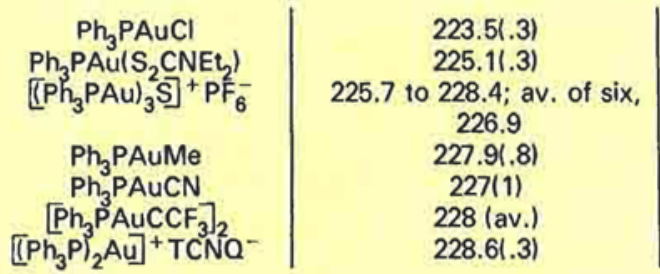

in some $\mathrm{R}_{3} \mathrm{PAuCl}$ species. Where $\mathrm{R}$ is an electronegative substituent, the Au-P bond length is shortened. This has been attributed (77) to contraction of the phosphorus lone pair rather than to increased $\mathrm{d} \pi \mathrm{d} \pi$ back donation. The $\mathrm{Au}-\mathrm{Cl}$ bond length is markedly affected only when the $\mathrm{Cl}$ ligand changes in nature from terminal to bridging

Further compounds in which the observed trends are as expected are $\mathrm{Ph}_{3} \mathrm{PAuX}$ (Table $\left.\mathrm{Vb}\right)$. These compounds seem to conform to Bent's rule, that bonds with the most $s$ character (the shortest bonds) are those to the least electronegative element. Thus, short $\mathrm{Au}-\mathrm{P}$ bonds are observed trans to $\mathrm{Cl}$ and $\mathrm{S}$. However, the changes observed are rather small. There is virtually no change in Au-P bond length for the series of organogold derivatives.
Complexes of some bidentate phosphine ligands have already been mentioned in Section IV.

The bis(phosphine) complex $\left[\left(\mathrm{Ph}_{2} \mathrm{MeP}\right)_{2} \mathrm{Au}\right]+\mathrm{PF}_{6}^{-}$ was the first $\mathrm{L}_{2} \mathrm{Au}^{+}$structure to be determined (80) and is exactly linear at $\mathrm{Au}$. A similar compound $\left[\left(\mathrm{cy}_{3} \mathrm{P}\right)_{2} \mathrm{Au}\right]^{+} \mathrm{SCN}^{-}(\mathrm{cy}=$ cyclohexyl) was investigated to ascertain whether the gold was two- or threecoordinate (81); the $\mathrm{SCN}^{-}$ion is in fact not coordinated to the metal. The $\mathrm{Ph}_{3} \mathrm{P}$ analogue has, however, been assigned a three-coordinate structure on the basis of its Mössbauer spectrum (82); steric effects may account for this difference.

The sole arsine complex to have been studied is $\mathrm{Ph}_{3} \mathrm{AsAuBr}(83)$; it is isostructural with $\mathrm{Ph}_{3} \mathrm{PAuCl}$, with bond lengths Au-As of $234.2(.5) \mathrm{pm}$ and $\mathrm{Au}-\mathrm{Br}$ of $237.7(.6) \mathrm{pm}$.

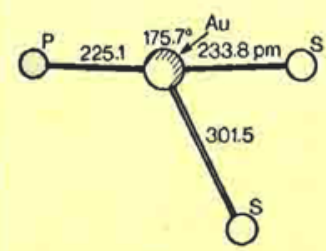

(a)

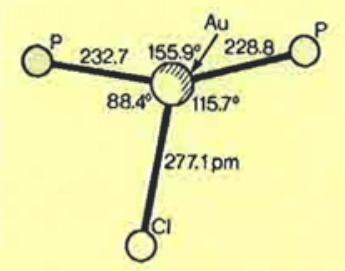

(e)

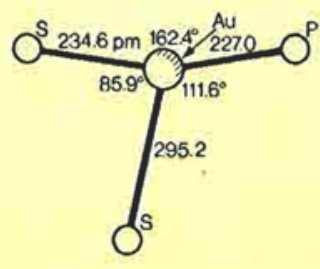

(b)

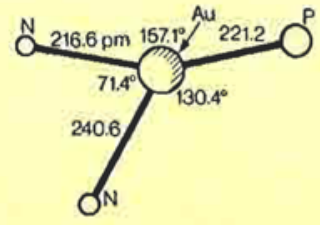

(c)

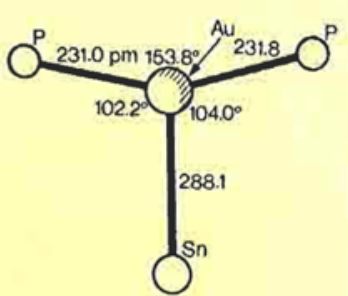

(d)

Fig. 21 Examples of irregular three-coordination of $\mathrm{Au}^{\mathrm{I}}$.

(a) $\left(\mathrm{Ph}_{3} \mathrm{P}\right) \mathrm{Au}\left(\mathrm{S}_{2} \mathrm{CNEt}_{2}\right)$, best regarded as two-coordinate. After (76)

(b) $\left(\mathrm{Ph}_{3} \mathrm{PAu}\right)_{2}\left(\mathrm{C}_{4} \mathrm{~S}_{4}\right)$ in which there are two identical Au environments per molecule. After (84)

(c) $\left[\left(\mathbf{P h}_{3} \mathbf{P}\right) \mathbf{A u}(\text { bipy) }]^{+}\right.$. After (85)

(d) $\left(\mathrm{Me}_{2} \mathrm{PhP}\right)_{2} \mathrm{AuSnCl}_{3}$. After (87)

(e) $\left[\mathrm{CH}_{2}\left(\mathrm{PPh}_{2}\right)_{2} \mathrm{AuCl}\right]_{2}$. After (55)

All these are drawn to the same scale 


\section{Gold(I) Complexes with Higher}

\section{Coordination Number}

Gold(I) complexes of the $\mathrm{L}_{2} \mathrm{AuX}$ type ( $\mathrm{L}=$ neutral ligand, $\mathrm{X}=$ anion which can also act as a ligand), [LAuL'] ${ }^{\prime}\left(\mathrm{L}^{\prime}=\right.$ potentially chelating neutral ligand $)$ or $\mathrm{LAuX}^{\prime}\left(\mathrm{X}^{\prime}=\right.$ potentially chelating anion) could, $a$ priori, exhibit three-coordination. It is a tribute to the preponderant tendency to two-coordination that several species of these types fail to achieve the higher coordination number; thus, $\left[\left(\mathrm{cy}_{3} \mathrm{P}\right)_{2} \mathrm{Au}\right]+\mathrm{SCN}^{-}$(81) and $\left[\mathrm{etu}_{2} \mathrm{Au}\right]^{+} \mathrm{Cl}^{-}(80)$ both contain non-coordinated anions, while the usually bidentate dtc ligand is monodentate in $\mathrm{Ph}_{3} \mathrm{PAu}\left(\mathrm{S}_{2} \mathrm{CNEt}_{2}\right)$ (76). Nevertheless, several examples of three-coordination are known. These may be conveniently divided into two categories - distorted and regular three-coordination - for the purpose of discussion.

\section{Distorted Three-Coordination}

It is clear that, if a bidentate ligand is sufficiently rigid, the coordination of one donor atom to a metal ion must result in the other donor atom being fairly close to that ion. In the case of gold(I), its tendency to two-coordination often results in bonds of widely differing strength (and length) being formed to the two donor atoms. Suitable criteria as to whether the resulting complex may be reasonably described as three-coordinate are (a) the length of the bond to the more weakly bound donor atom and (b) the deviation from linearity of the other bonds at the gold atom. Thus, the dtc complex (see Section V) has been described as two-coordinate, with an S-Au-P angle of $175.7^{\circ}$ and $\mathrm{Au}-\mathrm{S}$ distances of 233.8 and $301.5 \mathrm{pm}$. The tetrathiosquarate complex $\left[\left(\mathrm{Ph}_{3} \mathrm{PAu}\right)_{2}\left(\mathrm{C}_{4} \mathrm{~S}_{4}\right)\right](84)$, on the other hand, shows a somewhat stronger interaction between gold and the farther $\mathrm{S}$ atom (Au-S $=236.4$ and $295.2 \mathrm{pm}$ ) and a greater distortion of the larger S-Au-P angle (162.4 $\left.{ }^{\circ}\right)$; it may thus be described as three-coordinate. A similar example is $\left[\mathrm{Ph}_{3} \mathrm{PAu}\right.$ (bipy) $]+\mathrm{PF}_{6}^{-}(85)$, with $\mathrm{Au}-\mathrm{N}=216.6$ and $240.3 \mathrm{pm}$ and a P-Au-N angle of $157.1^{\circ}$.

A different type of ligand-imposed geometry is seen in (PP)AuCl $(86 \mathrm{nc})$, where $\mathrm{PP}$ is a bidentate phosphine ligand bridging trans coordination sites. The P-Au-P geometry is almost linear and the $\mathrm{Au}-\mathrm{Cl}$ bond is long (281.8 pm).

A compound which achieves distorted threecoordination without the constraints of bidentate ligands is $\left(\mathrm{Me}_{2} \mathrm{PhP}\right)_{2} \mathrm{AuSnCl}_{3}$ (87), with a P-Au-P angle of $153.8^{\circ}$ and a rather long $\mathrm{Au}-\mathrm{Sn}$ bond of $288.1 \mathrm{pm}$. A similar P-Au-P angle to this is observed in the dimer $\left[\left(\mathrm{Ph}_{2} \mathrm{P}\right)_{2} \mathrm{CH}_{2} \mathrm{AuCl}\right]_{2}$ (55), where the $\mathrm{Au}$ $\mathrm{Cl}$ bond (277.1 pm) is shorter than in (PP)AuCl.

Geometries of distorted three-coordinate complexes are summarized in Figure 21.

\section{Regular Three-Coordination}

The dividing line between regular and distorted three-coordination is clearly a subjective one; the rule chosen here is that 'regular' three-coordination involves no angle greater than $135^{\circ}$ at $\mathrm{Au}$.

In $\left[\left(\mathrm{Ph}_{2} \mathrm{MePAu}\right)_{2}\left(\mathrm{WS}_{4}\right)\right](88 \mathrm{nc})$ each PAu- moiety is bonded symmetrically to two $S$ atoms. The restricted 'bite' (distance between chelating donor atoms) of the $\mathrm{WS}_{2}$ group inevitably leads to some deviation from ideal geometry at $\mathrm{Au}$; the average S-Au-S and P-Au-S angles are 98 and $131^{\circ}$ respectively. It is interesting that the almost equal bite of the tetrathiosquarate ligand leads instead to distorted three-coordination (see above). The Au-S bonds are rather long (average $243 \mathrm{pm}$ ), but the Au-P bonds (average $227 \mathrm{pm}$ ) are of similar length to those in twocoordinate species.

The compounds $\left(\mathrm{Ph}_{3} \mathrm{P}\right)_{2} \mathrm{AuX}(\mathrm{X}=\mathrm{Cl}(89)$ or $\mathrm{I}(90))$ both show $\mathrm{P}$-Au-P angles somewhat wider than $120^{\circ}$ (132 and $131^{\circ}$ respectively) and P-Au bond lengths (average 233 and $234 \mathrm{pm}$ respectively) rather longer than in two-coordinate species. The latter is a normal trend with increase in coordination number. In addition, the $\mathrm{Cl}$ derivative shows a long (250.0 pm) Au-Cl bond consistent with the principle that the widest angle in trigonal species is opposite the weakest bond. The corresponding Au-I distance is $276.6 \mathrm{pm}$; no other Au-I bonds are available for comparison.

The most regular three-coordination is, not suprisingly, observed in compounds where all three ligands are identical, such as the ternary compounds $A u_{7} P_{10} I$ (1) (trigonal $\mathrm{AuP}_{3}$ moieties with $\mathrm{Au}-\mathrm{P}=233.9 \mathrm{pm}$ and P-Au-P $118.5^{\circ}$, site symmetry $3 m$ ) and $\mathrm{Tl}_{6} \mathrm{Au}_{2} \mathrm{I}_{10}$ (91) (two $\mathrm{AuI}_{3}$ units with Au-I $=274$ and $281 \mathrm{pm}-$ calculation from published coordinates and cell constants give $272,283 \mathrm{pm}$ - all angles $120^{\circ}$, site symmetries 32 and 6 respectively). The latter structure is however complicated by disorder. The only structures of non-polymeric materials with three identical ligands are those of $\left[\left(\mathrm{Ph}_{3} \mathrm{P}\right)_{3} \mathrm{Au}\right]^{+}$salts. Despite the cations being formally identical, significant differences are observed in structures of the $\mathrm{B}_{9} \mathrm{H}_{19} \mathrm{~S}^{-}$(92) and $\mathrm{BPh}_{4}^{-}$(93) salts. The thiadecaborate salt shows less regular geometry, the Au atom lying $30 \mathrm{pm}$ out of the $P_{3}$ plane.

Figure 22 summarizes the geometries of regular three-coordinate complexes.

Mention should also be made of the tetracyanoethylene complex $\left(\mathrm{Ph}_{3} \mathrm{P}\right)_{2} \mathrm{Au}(\mathrm{TCNE})$ (94nc), which may be regarded as three-coordinate, containing two Au-P and one Au-olefin bond; the P-Au-P angle is $133.7^{\circ}$.

\section{Four-Coordinate Complexes}

Four-coordinate gold(I) complexes have often been mentioned in the literature, but for many years only 


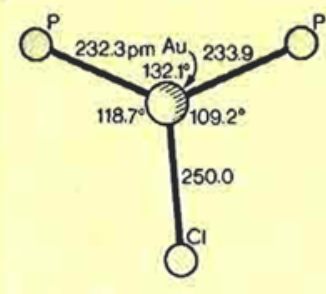

(a)

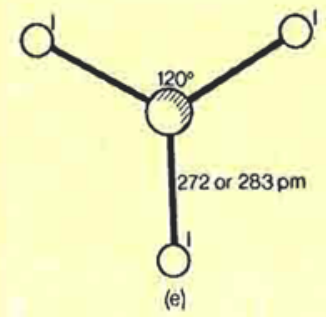



(b)

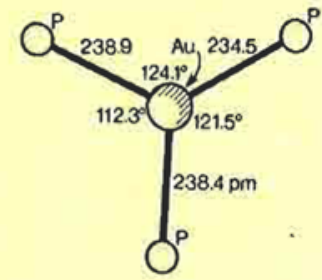

(c)

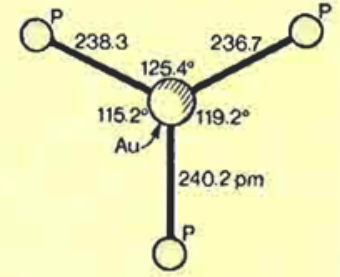

(d)

Fig. 22 Examples of regular three-coordination of $\mathrm{Au}^{\mathbf{1}}$.

(a) $\left(\mathrm{Ph}_{3} \mathrm{P}\right)_{2} \mathrm{AuCl}$. After (89)

(b) $\left(\mathrm{Ph}_{3} \mathbf{P}\right)_{2}$ Aul. After $(90)$

(c) $\left[\left(\mathrm{Ph}_{3} \mathrm{P}\right)_{3} \mathrm{Au}\right]^{+}$. After (92)

(d) $\left[\left(\mathrm{Ph}_{3} \mathrm{P}\right)_{3} \mathrm{Au}\right]^{+}$. After (93)

(e) two AuI ${ }_{3}$ moieties in $\mathrm{Tl}_{6} \mathrm{Au}_{2} \mathrm{I}_{10}$. After (91)

All these examples are drawn to the same scale (see Figures 1 and 12 for further examples). The structural principle that the weakest bond is opposite the largest angle, is generally well obeyed in the examples of Figures 21 and 22

one structure was known; that of $\mathrm{L}_{2} \mathrm{Au}^{+} \mathrm{I}^{-}$, where $\mathrm{L}$ is the bidentate arsenic ligand $o-\mathrm{C}_{6} \mathrm{H}_{4}\left(\mathrm{AsR}_{2}\right), \mathrm{R}=\mathrm{Et}$. In this early work, only $\mathrm{Au}$, As and I atoms were located (95). A recent study of the analogous cation $\left[(\text { diars })_{2} \mathrm{Au}\right]^{+}(\mathrm{R}=\mathrm{Me})(29)$ confirms its fourcoordinate nature. The symmetry is approximately $D_{2 d}$ (Figure 23), the bite of the ligand being too small to allow ideal tetrahedral coordination. Further exactly analogous structures have been observed for derivatives of cis-bis(diphenylphosphino)ethylene (96).
Four-coordinate complexes with monodentate ligands have only recently been studied crystallographically (97). The compound $\mathrm{L}_{4} \mathrm{Au}^{+} \mathrm{BPh}_{4}^{-}$ $\left(\mathrm{L}=\mathrm{Ph}_{3} \mathrm{P}\right.$ ) has long been known in powder form. Recrystallization leads to a variety of solvates, none of which shows the expected simple tetrahedral geometry. The chloroform solvate contains an $\mathrm{L}_{3} \mathrm{Au}$... L unit, with trigonal planar $\mathrm{L}_{3} \mathrm{Au}(\mathrm{Au}-\mathrm{P}=$ $240 \mathrm{pm}$ average) and a very long Au...L contact (395 $\mathrm{pm})$. The ethanol solvate possesses two alternative,

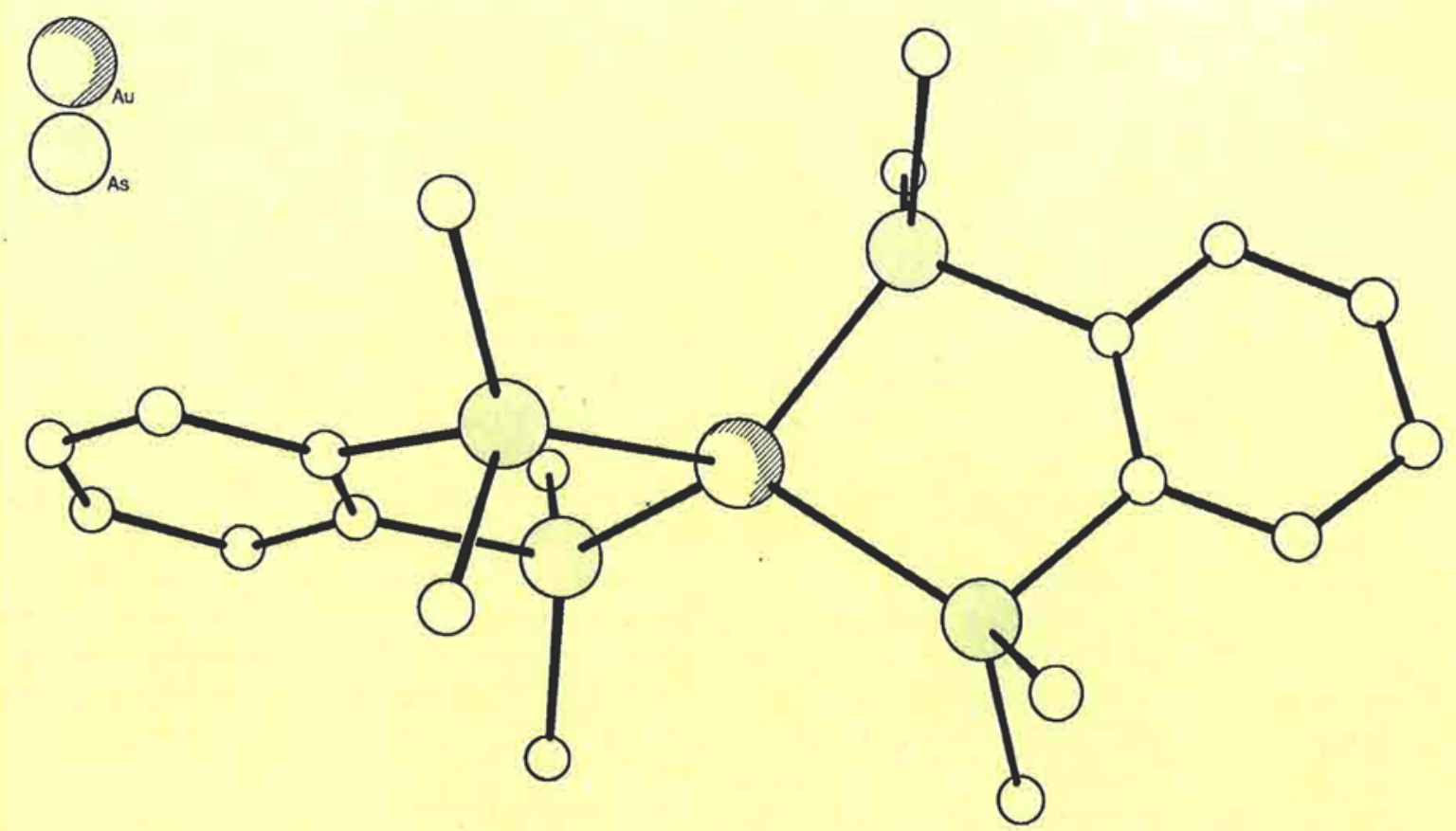

Fig. 23 The $\left[(\text { diars })_{2} A u\right]^{+}$cation, an example of four-coordinate $A u^{1}$ with chelating ligands. After (73) 
equally populated $\mathrm{Au}$ sites within an $\mathrm{L}_{4}$ 'cage'. One site is tetrahedraliy coordinated (site symmetry 2) with very long $\mathrm{Au}-\mathrm{P}$ bonds $(260,26 \mathrm{~lm})$, the other is trigonal with $\mathrm{Au}-\mathrm{P}=245 \mathrm{pm}$ on average. Finally, the isomorphous acetonitrile solvate was examined at $-150^{\circ} \mathrm{C}$ in an attempt to 'freeze out' the disorder into one component. The disorder remains, but with a 7:1 ratio of tetrahedral to trigonal sites. The question whether gold(I) can show simple tetrahedral geometry without these disorder components remains unanswered.

\section{References}

1 W. Jeitschko and M. H. Möller, Acta Crystallogr., 1979, B35, 573-579

la C. Mues and H.-U. Schuster, Z. Naturforsch., 1980, 35b, 1055-1058

2 P. G. Jones, H. Rumpel, E. Schwarzmann, G. M. Sheldrick and H. Paulus, Acta Crystallogr., 1979, B35, 1435.1437

3 P. G. Jones, H. Rumpel, E. Schwarzmann and G. $M$ Sheldrick, Acta Crystallogr., 1979, B35, 2380-238

4 A. Rabenau and H. Schulz, 7 . Less Common Met., 1976, 48, 89-101

5 D. Mootz, A. Rabenau, H. Wunderlich and G. Rosenstein, 7. Solid State Chem., 1973, 6, 583.586

6 H. M. Haendler, D. Mootz, A. Rabenau and G. Rosenstein, f. Solid State Chem., 1974, 10, 175-184

7 G. Tunell and C. J. Ksanda, Y. Washington Acad. Sci., 1935 25, 32-33

8 G. Tunell and K. J. Murata, Am. Mineralog., 1950, 35, 959-984

9 F. W. B. Einstein, P. R. Rao, J. Trotter and N. Bartlett, $y$. Chem. Soc. A, 1967, 478-482

10 E. S. Clark, D. H. Templeton and C. H. MacGillavry, Acta Crystallogr., 1958, 11, 284-288

11 K.-P. Lörcher and J. Strähle, Z. Naturforsch., 1975, 30b, 662-664

12 E. M. W. Janssen, J. C. W. Folmer and G. A. Wiegers, $y$ Less Common Met., 1974, 38, $71-76$

13 J. Strähle and K.-P. Lörcher, Z. Naturforsch., 1974, 29b, 266-267

14 A. Weiss and A. Wejss, Z. Naturforsch., 1956, 11b, 604

15 H. Jagodzinski, Z. Kristallogr., 1959, 112, 80-87

15a E. M.W. Janssen and G. A. Wiegers, Y. Less Common Met, 1978,57, P47-P57

16 H. Zhdanov and E. Shugam, Acta Physicochem. URSS, 1945, 20, 253-258

17 J. W. A. van der Velden, J. J. Bour, F. A. Vollenbroek, '?' T. Beurskens and J. M. M. Smits, F. Chem. Soc. Chem. Commun., 1979, 1162-1163

18 P. Bellon, M. Manassero and M. Sansoni, J. Chem. Soc Dalton Trans., 1973, 2423-2427

19 M. Manassero, L. Naldini and M. Sansoni, 7. Chem. Soc Chem. Commun, 1979, 385-386

20 F. A. Vollenbroek, W. P. Bosman, J. J. Bour, J. H. Noordik and P. T. Beurskens, $\mathcal{X}$. Chem. Soc. Chom. Commun, 1979, 387-388

21 P. L. Bellon, F. Cariati, M. Manassero, L. Naldini and $M$ Sansoni, Y. Chem. Soc. Chem. Commun., 1971, 1423-1424

22 M. McPartlin, R. Mason and L. Malatesta, $y$. Chem. Soc Chem. Commun., 1969, 334

23 V. G. Albano, P. I. Bellon, M. Manassero and M. Sansoni, 7. Chem. Soc. Chem. Commun., 1970, 1210-1211

24 P. Bellon, M. Manassero and M. Sansoni, $\mathscr{F}$. Chem. Soc Dalton Trans., 1972, 1481-1487

25 H. M. Powell, K. A. I. F. M. Mannan, B. T. Kilbourn and R. Porta, Int. Conf. Coord. Chem, 1964, 8, 155-157

26 K. A. I. F. M. Mannan, Acta Crystallogr, 1967, 23, 649-653

27 J. B. Wilford and H. M. Powell, J. Chem. Soc. A, 1969, 8-15

28 T. L. Blundell and H. M. Powell, 9 , Chem. Soc. A, 1971, $1685-1690$

29 R. Uson, A. Laguna, M. Laguna, P. G. Jones and G. M. Sheldrick, \%. Chem. Soc. Dalton Trans., 1981, 366-370

$30 \mathrm{~J}$. Gee and H. M. Powcll (unpublished), reported in C. W. Bradfield, W. van Bronswijk, R. J. H. Clark and R. S. Nyholm, Y. Chem. Soc. A, 1970, 2889-2899

30a P. R. Raithby, private communication
31 V. G. Adrianov, Y. T. Struchkov and E. R. Rossinskaya, Zk. Strtkt. Khim., 1974, 15, 74-82 (pp. 65-72 in the English transiation)

32 W. B. Pearson, 'Latrice Spacings and Structure of Metals and Alloys', Pergamon Press, London, 1957

33 F. J. Farrell and T. G. Spiro, Inorg. Chem., 1971, 10, 1606-1610

34 G. J. Arai, Recl. Trav. Chim. Pays-Bas, 1962, 81, 307-312

35 P. W. R. Corfield and H. M. M. Shearer, Acta Crystallogr., $1967,23,156-162$

36 M. G. B. Drew and M. J. Riedl, f. Chem. Soc, Dallon Trans., 1973, 52-55

37 J. J. Guy, P. G. Jones, M. J. Mays and G. M. Sheldrick, f Chem. Soc, Dalton Trans., 1977, 8-10

37a H. -N. Adams, $M$. Kölmel, J. Strähle and $M$. Weishaupt, in 'Abstr. Eur. Crystallogr. Meeting', 1977, p. 200

$37 \mathrm{~b} \mathrm{H.} \mathrm{-N.} \mathrm{Adams,} \mathrm{Ph.D.} \mathrm{Dissertation,} \mathrm{Univ.} \mathrm{of} \mathrm{Tübingen,}$ 1980

38 R. F. Baggio and S. Baggio, 7. Inorg. Nucl. Chem., 1973, 35 3191.3200

39 H. Ruben, A. Zalkin, M. O. Faltens and D. H. Templeton, Inorg. Chem., 1974, 13, 1836-1839

40 C. J. Gilmore and P. Woodward, F. Chem. Soc. Chem. Commun., 1971, 1233-1234

41 R. Hesse and P. Jennischc, Acta Chem. Scand., 1972, 26 3855-3864

42 P. Jennische, H. Anacker-Eickhoff and A. Wahlberg, Acta Crystallogr., 1975, A31, S143

43 P. Jennische, Uppsala University Institute of Chemistry, Publication B20-02, 1976

44 S. L. Lawton, W. J. Rohrbaugh and G. T. Kokotailo, Inorg. Chem., 1972, 11, 2227-2233

44a O. Piovesana and P. F. Zanuzzi, Angew. Chem., 1980, 92 579.580

45 H. Schmidbaur, A. Wohlleben, F. Wagner, O, Orama and G. Huttner, Chem. Ber., 1977, 110, 1748-1754

46 P. G. Jones, Acta Crystallogr., 1980, B36, 2775-2776

47 P. G. Jones, G. M. Sheldrick, R. Uson and A. Laguna, Acto Crystallogr., 1980, B36, 1486-1488

48 P. G. Jones, G. M. Sheldrick and E. Hädicke, $A c t a$ Crystallogr., 1980, B36, 2777-2779

49 D. B. Dell'Amico, F. Calderazzo, F. Marchetti, S. Merino and G. Perego, $\mathcal{Y}$. Chem. Soc. Chem. Commun., 1977, 31-32

50 A. Tiripicchio, M. T. Camellini and G. Minghetti, $f$. Organomet. Chem., 1979, 171, 399-406

51 W. S. Crane and H. Beall, horg. Chim. Acta, 1978, 31, L469-L470

52 H. Schmidbaur, J. E. Mandl, W. Richter, V. Bejenke, A Frank and G, Huttner, Chem, Ber, 1977, 110, 2236-2241

52a H. Schmidbaur, J. R. Mandl, J. .M. Bassett, G. Blaschke and B. Zimmer-Gasser, 1981, 114, 433-440

$53 \mathrm{H}$. Schmidbaur, H. .P. Scherm and U. Schubert, Chem. Ber., 1978, 111, 764-769

54 A. Müller, H. Dornfield, G. Henkel, B. Krebs and M. P. A Viegers, Angew. Chem., 1978, 90, 57-58 (bond lengths quoted in (57))

55 H. Schmidbaur, A. Wohlleben, U. Schubert, A. Frank and G. Huttner, Chem. Ber, 1977, 110, 2751-2757

56 C. L. Teske, Z. anorg, allg. Chem., 1978, 445, 193-201

57 J. Strähle, J. Gelinek and M. Kölmel, Z. anorg. allg. Chem., $1979,456,241-260$

58 W. Werner and J. Strähle, Z. Naturforsch., 1979, 34b 952-956

59 R. E. Rundle, 7. Am. Chem. Soc, 1954, 76, 3101-3102

60 W. Falkenberg, E. Höhne, J. Sieler and R. Wagner, Krist. Tech., 1973, 8, 227-235

61 J. C. M. Tindemans-van Eijndhoven and G. C. Verschoor, Mater. Res. Bull., 1974, 9, 1667-1670

62 P. T. Beurskens, H. J. A. Blaauw, J. A. Cras and J. J. Steggerda, Tnorg. Chem., 1968, 7, 805-810

$63 \mathrm{~J}$. Strähle, J. Gelinek, M. Kölmel and A. -M. Nemecek, $Z$ Naturforsch., 1979, 34b, 1047-1052

64 H. -D. Wasel-Nielen and R. Hoppe, Z. anorg. allg. Chem., $1968,359,36-40$

65 N. A. Malik, P. J. Sadler, S. Neidle and G. L. Taylor, $f$ Chem. Soc. Chem. Commun., 1978, $711-712$

66 P. L. Bellon, M. Manassero and M. Sansoni, Ric. Sci., 1969 39, $173-175$

67 A. Rosenzweig and D. T. Cromer, Acta Crystallogr., 1959 $12,709.712$

68 H. J. Dothie, F. J. Llewellyn, W. Wardlaw and A. J. E. Welch, y. Chem. Soc., 1939, 426-428

69 P. G. Jones, W. Clegg and G. M. Sheldrick, Acta Crystallogr,, 1980, B36, 141-142 
70 S. Esperàs, Acla Chem. Scand., 1976, A30, 527-530

71 U. Nagel, K. Pelers, H. G, von Schnering and W. Beck, $f$ Organomet. Chem., 1980, 185, 427-432

72 R. W. Baker and P. Pauling, \%. Chem. Soc. Dalton Trans., $[972,2264-2266$

73 R. Uson, A. Laguna, J. Vicente, J. Garcia, P. G. Jones and G. M. Sheldrick, 7 . Chem. Soc. Dalton Trans., 1981 655-657

74 P. D. Gavens, J. J. Guy, M. J. Mays and G. M. Sheldrick, Acta Crystallogr., 1977, B33, 137-139

74a J. A. J. Jarvis, A. Johnson and R. J. Puddephatt, f. Chem Soc. Chem. Commun., 1973, 373-374

74b I'. G. Jones, A. G, Maddock, M. J. Mays, M. M. Muir and A. F. Williams, 7. Chem. Soc. Dalton Trans., 1977 , 1434-1439

75 P. G. Jones, J. J. Guy and G. M. Sheldrick, Acta Crystallogr, 1976, B32, 3321-3322

76 J. G. Wijnhoven, W. J. P. H. Bosman and P. T. Beurskens, 7. Cryst. Mol. Struct., 1972, 2, 7.15

77 P. B. Hitcheock and P. L. Pye, J. Chem. Soc. Dalton Trans. $1977,1457-1460$

78 N. C. Baenziger, W. E, Bennett and D. M. Soboroff, Acta Crystallogr, 1976, B32, 962-963

79 W. E. Bennett, D. M. Soboroff and N. C. Baenziger, unpublished work, reported in (89)

80 J. J. Guy, P. G. Jones and G. M. Sheldrick, Acta Crystallogr, 1976, B32, 1937-1938

81 J. A. Muir, M. M. Muir and E. Lorca, Acta Crystallogr. $1980, \mathbf{B 3 6}, 931-933$
82 G. C. H. Jones, P. G. Jones, A. G. Maddock, M. J. Mays, I' A. Vergnano and A. F. Williams, \%. Chem. Soc, Dallon Trans., 1977, I440-1443

83 F. W. B. Einstein and R. Restivo, Acta Crystallogr., 1975 B31, 624-626

84 P. G. Jones, G. M. Sheldrick, A. Fügner, F. Götzfried and W. Beck, Chem. Ber, 114, 1413-1417

85 W. Clegg, Acta Crystallogr., 1976, B32, 2712-2714

86 M. Barrow, H. B. Bürgi, D. K. Johnson and L. M. Venanzi, 7. Am. Chem. Soc., 1976, 98, 2356-2357

87 W. Clegg, Acta Crystallogr., 1978, B34, 278-281

88 J. C. Huffmann, R. S. Roth and A. R. Siedle, $\mathscr{7}$. Am. Chem. Soc, $1976,98,4340-4341$

89 N. C. Baenziger, K. M. Dittemore and J. R. Doyle, Inorg Chem., 1974, 13, 805-810

90 J. Strähle and G, Beindorf, private communication G. Beindorf, Diplomarbeit, University of Tübingen, 1978

91 W. Stoeger and A. Rabenau, Z. Naturforsch, 1979, 34b 685-692

92 L. J. Guggenberger, f. Organomet. Chem., 1974, 81, 271-280

93 P. G. Jones, Acta Crystallogr., 1980, B36, 3105-3107

94 T. H. Berg, N. C. Baenziger and J. R. Doyle, $A m$ Crystallogr. Assoc., Series 2, 1978, 6, 15

95 W. Cochran, F. A. Hart and F. G. Mann, f. Chem. Soc., 1957, 2816-2828

96 P. G. Jones, in preparation

97 P. G. Jones, J. Cham. Soc. Chem. Commun., 1980 1031-1033

Part II of this article will be published in the October 1981 issue of Gold Bulletin.

\section{Gold in Bubble Memories}

Bubble memories are microelectronic serial-access information devices in which data from a storage film of garnet are carried as microscopic domains of magnetic polarization in a separate drive layer of garnet grown epitaxially on the storage layer. These domains appear as bubble-like discs when viewed with polarized light. A new type of device, which is currently being developed, utilizes gold films in the movement of information bubbles.

Existing information storage devices, in which magnetic bubbles are carried by travelling potential wells in Permalloy chevron-elements, presently offer a storage density of about 1 million bits $(\mathrm{Mb})$ per square centimetre with a possibility of achieving $1.5 \mathrm{Mb} / \mathrm{cm}^{2}$. This, however, would strain the capabilities of the photo-lithographic technology used in the manufacture of the devices, due to the very high resolution required to produce parts of the circuit pattern which should have dimensions of a fraction of the bubble diameter - for example, sub-micrometre dimensions in the case of a $1 \mu \mathrm{m}$ bubble.

A recent article (IEEE Spectrum, 1981, 18, (2), 30-34) by $S$. Lin and I. L. Saunders, of IBM San Jose Research Laboratory, discusses the possible replacement of the current technology with a new generation of contiguouselement magnetic bubble devices in which the elements are undulating gold deposits. Devices in development at present have a storage density of $4 \mathrm{Mb} / \mathrm{cm}^{2}$, and $16 \mathrm{Mb} / \mathrm{cm}^{2}$ appears within reach with standard production methods.

In the proposed contiguous-disc bubble circuitry, Permalloy propagation patterns are not involved and the bubbles are moved not under the circuit pattern, but alongside it. Thus, lithographic features greater than the bubble diameter are permitted, yielding possible storage densities of $4 \mathrm{Mb} / \mathrm{cm}^{2}$ for $1 \mu \mathrm{m}$ bubbles and $16 \mathrm{Mb} / \mathrm{cm}^{2}$ for $0.5 \mu \mathrm{m}$ bubbles.

In these contiguous-disc devices, the gold circuit pattern acts primarily as a mask for ion implantation to alter the magnetic characteristics of the surface garnet layer. The gold patterns may also carry the currents that provide the magnetic fields for such functions as bubble generation and switching. The flow of magnetization within the garnet, resulting from an applied magnetic field which is forced into the plane of the drive layer as a result of ion implantation of the structure, bends around the gold discs - more accurately diamonds or triangles - like the flow of a river around islands, forming diverging and converging charged walls which attract the memory bubbles and carry them along as the walls rotate with the in-plane magnetic field. This behaviour was depicted by Lin and Saunders in the diagram shown below.

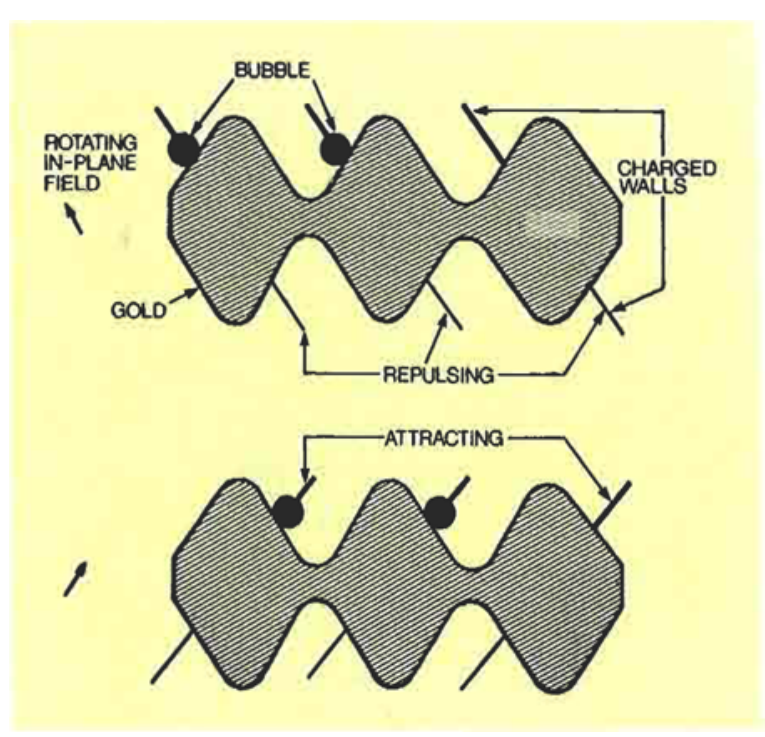

